\title{
'Tipping the Balance': Karl Friedrich Meyer, Latent Infections, and the Birth of Modern Ideas of Disease Ecology
}

\author{
MARK HONIGSBAUM \\ London \\ $U K$ \\ E-mail:mark.honigsbaum@qmul.ac.uk
}

\begin{abstract}
The Swiss-born medical researcher Karl Friedrich Meyer (1884-1974) is best known as a 'microbe hunter' who pioneered investigations into diseases at the intersection of animal and human health in California in the 1920s and 1930s. In particular, historians have singled out Meyer's 1931 Ludwig Hektoen Lecture in which he described the animal kingdom as a 'reservoir of disease' as a forerunner of 'one medicine' approaches to emerging zoonoses. In so doing, however, historians risk overlooking Meyer's other intellectual contributions. Developed in a series of papers from the mid-1930s onwards, these were ordered around the concept of latent infections and sought to link microbial behavior to broader bio-ecological, environmental, and social factors that impact hostpathogen interactions. In this respect Meyer-like the comparative pathologist Theobald Smith and the immunologist Frank Macfarlane Burnet - can be seen as a pioneer of modern ideas of disease ecology. However, while Burnet's and Smith's contributions to this scientific field have been widely acknowledged, Meyer's have been largely ignored. Drawing on Meyer's published writings and private correspondence, this paper aims to correct that lacuna while contributing to a reorientation of the historiography of bacteriological epidemiology. In particular I trace Meyer's intellectual exchanges with Smith, Burnet and the animal ecologist Charles Elton, over brucellosis, psittacosis and plague - exchanges that not only showed how environmental and ecological conditions could 'tip the balance' in favor of parasites but which transformed Meyer thinking about resistance to infection and disease.
\end{abstract}

Keywords: Bacteriology, Parasitology, Disease ecology, Latent infections, Psittacosis, Plague

On 27 December 1935, Karl Friedrich Meyer prepared to give the presidential address to the Society of American Bacteriologists in New York. Then aged 51, Meyer was spoiled for choice of topics. Since joining the George Williams Hooper Foundation for Medical Research in San Francisco in 1921, Meyer had addressed the problem of brucellosis in raw "certified milk", helped the Californian canning industry eradicate botulism from canned foods, and worked tirelessly with bird 
breeders to contain the spread of psittacosis, a deadly bacterial disease of parrots and parakeets. Now, in cooperation with the Californian public health service, Meyer was heading up a state-wide investigation into sylvatic plague, the cause, it was believed, of recent human outbreaks in Los Angeles and counties along the Californian-Oregon border.

Meyer's recognition that animals were often infected with the same parasites as people had led to his characterization 4 years earlier in his Ludwig Hektoen lecture of the animal kingdom as "a reservoir of disease" and his call for infectious disease to be studied "on a strictly comparative basis" (Meyer, 1931). However, the topic chosen by Meyer for his address to the Society of American Bacteriologists was none of these - at least, not directly. Instead, Meyer chose to speak on 'latent infections' (Meyer, 1936a).

Ever since Robert Koch had drawn attention to the phenomenon of healthy "cholera carriers" in Hamburg in 1893, the list of diseases in which bacteria had been isolated in the blood and tissues of otherwise healthy individuals had been growing. ${ }^{1}$ By the 1920 s, these latent infections included typhoid, diphtheria, plague, dysentery, cerebrospinal meningitis, acute poliomyelitis, pneumococcus pneumonia, streptococcal infections, and influenza (Chapin, 1910, Ledingham, 1912, Simon, 1919). However, as the list of asymptomatic or symptomless infections had grown so too had the proliferation of synonyms for these latent or carrier states. To add to this taxonomical confusion, many of these infections were invisible to clinicians and only became apparent at autopsy or in the laboratory through the application of specialized serology and antigen tests. It was in an attempt to introduce clarity into the discussion that Meyer had undertaken a comprehensive review of the scientific literature. In a speech that ranged widely across bacteriology, zoology, botany and biology, Meyer suggested that far from clarifying understandings of the difference between infection and disease the proliferation of synonyms for latent infections had only served to confuse the picture. Instead of asking whether or not an infection was latent, Meyer suggested that it might be more profitable to ask what were the factors and conditions that converted a microbial pathogen from a state of "symbiosis" with its host-in which it caused infection without disease - to one in which the invasion of blood and living tis-

${ }^{1}$ Koch used various terms to describe this phenomenon first observed during the second cholera epidemic in Hamburg in the winter of 1893 but the most common were Choleragesunden, literally "cholera healthy person", and Bazillentrager or "bacillus carrier" (Mendelsohn, 1996). 
sues resulted in visible lesions and/or symptoms. To answer that question, Meyer suggested it was necessary to "analyze medical bacteriologic phenomena from a general biologic point of view" [italics inserted]. Rather than seeing latent infections as manifestations as of an incipient or early form of parasitism, he argued, the reverse might be the case such that "benign parasites evolve from harmful ones."

In the light of modern biological thinking which gradually permeates the utilitarian concepts of medical bacteriology it is believed, although by no means proven, that the infection without symptoms is the sequel and not its precursor... It appears that the gradual and more intimate adaptation to a host and to its mode of living more or less improves the existence of the parasitic species. Simultaneously with this adaptation the ability to invade other hosts is progressively lost [italics in original]... Viewed from this angle, it is obvious that the slowly fatal or chronic illness of the host is of greater advantage to the parasite than the rapidly deadly or rapidly cured malady. The highest type of adaptation is recognized as the life-long infection of the host (Meyer, 1936a, pp. 120-121).

Meyer's belief that long-term biological associations between hosts and parasites favor avirulent, subclinical infections would today be dismissed as naïvely adaptationist. Since the early 1980s, the mathematical model of the trade-off-based on the idea that pathogens face several compromises between their mode of transmission, the level of virulence, and the cost of resistance-has challenged the assumption that parasites, whether conceived of as bacteria, viruses or protozoa, tend to evolve towards equilibrium states or commensalism with hosts (Alizon et al., 2009; Ewald, 2004; Méthot, 2012). Yet in the 1930s Meyer and others-most notably the comparative pathologist Theobald Smith - argued strongly that infection ought to be seen in bio-ecological terms as an expression of what Smith called a "host-parasite equilibrium" and what Meyer, in his 1935 talk, called "a slow, orderly, evolutionary adaptation to the new hosts" (Smith, 1934, p. 216; Meyer, 1936a, p. 125). By the early 1940s, these ideas were also appearing in the writings of the Australian immunologist and Nobel Prize winner Frank Macfarlane Burnet and the French-born American microbiologist and Rockefeller researcher René Dubos (Burnet, 1940; Dubos, 1955, 1958). However, while Burnet, Dubos, and Smith's contributions to modern ideas of disease ecology have been the subject of much scholarship, Meyer's contribution to this strand within medical microbiology has been largely ignored (Zabusky, 1986; Cooper, 1998, Dolman, 2003; 
Anderson, 2004; Moberg, 2005; Méthot, 2012). Nor have medical historians shown much interest in examining how Meyer's changing ideas about disease were shaped by his broad-based medical education in Switzerland and his formative years as a veterinary pathologist in South Africa and, later, as a medical researcher in California (Gessner, 2014). This is somewhat odd given Meyer's claim in 1961 in an interview with Edna Tartaul Daniel, an oral historian employed by the Regents Office of the University of California, that he had first begun thinking about disease in biological terms as early as 1928, in other words long before the publication of Burnet's Biological Aspects of Infectious Disease and 6 years before the publication of Smith's Parasitism and Disease. ${ }^{2}$ It was this "biological approach" that Meyer informed Daniel had led him to the concept of latent infections and the idea that "the ultimate outcome of an infection is controlled by the genetic history of the parasite and the genetic history of the host" (Meyer, 1976, pp. 254-255).

When Meyer's turn to biology also became a turn to ecology-and what, precisely, Meyer meant by ecology - is more difficult to ascertain. When the British animal ecologist Charles Elton visited Meyer in San Francisco in 1938 he records in his diary that he found Meyer "already talking business and ecology" (Elton, 1938a). However, Meyer's first explicit use of the term came in two lectures at Johns Hopkins' School of Hygiene and Public Health in 1941 on respectively the "Ecology of Plague" and the "Ecology of Psittacosis and Ornithosis" (Meyer, 1942a, b). Nevertheless, Meyer's protégés have portrayed him as a prescient and farsighted ecological thinker, citing as evidence his decision in the late 1950 s to reorient the Hooper's research program towards the study of "animal and human ecology". ${ }^{3}$ As his former PhD student Julius Schachter, now professor of laboratory medicine at the University of California San Francisco, puts it: "KF was, in fact, a biologist. Long before ecology became a magic password... Meyer practiced the approach" (Meyer, 1976, pp. 380-386).

Rather than uncritically accepting such claims, this paper aims to trace Meyer's intellectual development in relation to his medical career and his scientific research. In particular, I focus on Meyer's attempts to make sense of the chronicity of epidemics of equine encephalitis, psittacosis and plague - diseases that, by the 1960s, Meyer would identify as

2 Smith's book was published in 1934, while Biological Aspects was published in 1940, though Burnet claimed he had begun work on the manuscript in 1936-1937 (Burnet, 1953, p. xi).

${ }^{3}$ Interview with Julius Schachter, professor of laboratory medicine, University of California San Francisco, San Francisco, 24 February 2014. See also Anon (1965) and Audy (1965). 
having played a key role in his turn to ecology in the late 1930s. Instead of accepting the older Meyer's claims at face value, I aim to recover the outlook of the younger Meyer and examine how his ecological ideas were shaped by his encounters with new infectious diseases that presented a pressing public health threat in California in the interwar period and his exchanges with other scientific researchers both within and outside of medical microbiology. ${ }^{4}$ In so doing, I aim to resist the revisionist temptation to denigrate the achievements of bacteriological epidemiology in the interwar period. Instead, my account privileges its flexibility as an experimental practice and the way that its practitioners were able to incorporate insights from other disciplines, such as parasitology, biology, zoology and animal ecology, into their evolving disease models.

This paper can also be seen as a contribution to the debate about the extent to which bio-ecological ideas emerged from within medical microbiology and the practices of bacteriological epidemiology as opposed to being imports from other disciplines and scientific fields. Posing the question in 1998 "where did the modern, ecological understanding of infectious disease come from?", J. Andrew Mendelsohn argued that it was hard to see how "the fledgling ideas and methods of upstart population ecology, or the premises of parasitology could have conquered bacteriology". In particular, Mendelsohn chided Burnet for having "left out half the story" when in 1940 he had claimed in Biological Aspects of Infectious Disease that the new "ecological point of view" had been due to the ascendance of other scientists over "bacteriologists [who] were trained as medical men" (Burnet, 1940, pp. 2-3). Instead, Mendelsohn suggested the conquest had come "from within" bacteriology and was already well underway when the 1918-19 influenza pandemic and the emergence of 'new' diseases, such as cerebrospinal meningitis, poliomyelitis, and encephalitis lethargica, in the post-war period compelled bacteriological epidemiology to become "more complex" (Mendelsohn, 1998, pp. 303-304). By contrast, other scholars have pointed to the influence of tropical medicine and parasitology, in particular the work of turn-of-the century British scientists drawn to the study of malaria and trypanosomiasis in Africa (Worboys, 1988, Farley, 1992, Tilley, 2004). Similarly, tracing the "ecological visions" of Burnet, Dubos, Smith and Frank Fenner, Warwick Anderson has suggested that the turn to ecology within medical microbiology was spurred by

4 The principal biographical sources for Meyer are Daniel's 1961-62 oral history and the series of interviews that Dr Carter and Dr Link conducted with Meyer in the late 1950s (Meyer, 1976, Carter and Link, 1956). 
insights from tropical medicine, veterinary pathology and immunology, as well as by medical researchers' encounters with parasitical and viral diseases in "settler societies" such as Australia - an intellectual shift that, he has argued, was aided and abetted by the transference of ecological ideas across institutional and disciplinary boundaries via transnational scientific networks (Anderson, 2004). ${ }^{5}$ Indeed, in a recent paper Anderson suggests that Burnet's embrace of ecological ideas was inspired, in part, by his "cosmopolitan" exchanges with British epidemiologists and animal ecologists, some of whom had trained under Elton at Oxford and who passed through Canberra and Melbourne in the 1930s (Anderson, 2015). In this paper, I suggest that Meyer's embrace of ecological perspectives was similarly influenced by his exchanges with Smith, Burnet and Elton-exchanges that were prompted by Meyer's studies of brucellosis, equine encephalitis, psittacosis and plague but which soon encompassed wider questions about host-parasite interactions and the nature of 'equilibrium' states and the emergence of 'new' diseases in the interwar period. In this way, I argue, Meyer deserves to be seen as an important bridge figure in mid-twentieth century medical research that sought to link microbial behavior to broader bio-ecological, environmental and social factors that impact host-pathogen interactions and the mechanisms of disease control (Honigsbaum, 2014).

\section{Structure and Methodology}

The first part of this paper presents a sketch of Meyer's educational formation and his key intellectual influences, in particular his relationship with Theobald Smith and their exchanges on brucellosis. The next three sections detail his investigations of equine encephalitis, psittacosis and plague, and the influence these investigations had on his evolving biological and ecological ideas. In particular, I argue that Meyer's arrival in San Francisco in 1913 coincided with a period of rapid population growth in California that saw the incursion of agricultural settlers into valleys and deserts teeming with arthropod-bearing parasites and exotic fauna. In order to divine the etiology of the diseases that confronted him in this Western settler society and solve the puzzle of their

\footnotetext{
${ }^{5}$ In recent years, several scholars have used the term "settler societies" to refer to the way that ecological conceptions of infectious disease were influenced by the settlement of new territories and scientists' encounters with the novel pathogens that bred in these unfamiliar environments. See, for instance, Griffiths and Robin (1997), Mitman (1992), Nash (2006), Anderson (2004, 2015).
} 
epidemicity Meyer was forced to venture beyond the Hooper and UCSF medical school, fostering exchanges with scientists in other universities, institutions and disciplinary domains, including zoology, entomology and animal ecology. These intellectual exchanges included both prominent American scientists such as Smith and international researchers such as Burnet whose encounters with novel pathogens in Australia mirrored Meyer's experiences in California. In addition, I show how Meyer reached out to Elton, the director of the Bureau of Animal Population at Oxford University and then the world's leading authority on animal ecology, for advice on the ecology of sylvatic plague and for political support in Meyer's battles with state public health officials and members of the Berkeley faculty. Rather than seeing the modern biological and ecological understanding of infectious disease as a product of the post-1957 breakthrough in bacterial genetics, as Joshua Lederberg has argued, my account stresses the continuity between earlier Pasteurian ideas of microbial life and the more complex, fully formed biological ideas about bacteria and viruses that emerged in the second half of the twentieth century (Lederberg, 2000). At the same time, I examine how terms such as 'latency', animal 'reservoirs,' 'symbiosis' and 'balance' provided Meyer with metaphors to bridge the conceptual deficits in bacteriological epidemiology in the 1930s. In the fifth and final part, I reflect on how Meyer's exchanges with Smith, and Elton and his employment of these metaphors shaped his evolving biological and ecological ideas and draw some tentative conclusions.

\section{Biographical Sketch and Intellectual Formation}

If Meyer is remembered at all today it is usually as a pioneer in the field of veterinary epidemiology and a forerunner of 'one medicine/one health' approaches to the study of zoonotic diseases (Gessner, 2014; Kahn et al., 2007). However, although Meyer's first degree was in veterinary medicine, he was also a skilled pathologist and clinical observer and the breadth of his scientific interests and technical accomplishments make it difficult to sum him up in a few words or a succinct phrase. Opening his biographical memoir, Albert Sabin, who got to know Meyer in the 1940s when they served together on the National Foundation for Infant Paralysis, plumped for "outstanding bacteriologist, experimental pathologist, virologist, epidemiologist, ecologist" (Sabin, 1980), while Meyer's friend, the science writer Paul De Kruif, famously hailed him as "the most versatile microbe hunter since Pasteur" (De Kruif, 1950). 
However Sabin and De Kruif might equally have described Meyer as a parasitologist and zoologist - in 1909 he became the first person to elucidate the life cycle of the plasmodium of East Coast Fever, and his PhD from the University of Zurich, awarded in 1924, was for a study of 'bacterial symbiosis' in mollusks (Gessner, 2014; Meyer, 1925).

For his own part, accepting the Walter Reed Medal for Services to Tropical Medicine at the American Society of Tropical Medicine and Hygiene in New Orleans in 1956, Meyer suggested that it was his early fascination with the life cycle of the malaria parasite and the trypanosomes of sleeping sickness that had first fueled his interest in infectious disease and persuaded him to enroll in a course in protozoology under Friedrich Zschokke at the University of Bern (Meyer 1957a). Another formative influence was Heinrich Zangger, professor of comparative physiology and pathology at the veterinary school in Zurich (Meyer 1976, p. 31). For all Meyer's interest in parasitology, however, he was very much a product of the German bacteriological tradition. Meyer's grounding in this science, with its demanding techniques of bacterial cultivation, staining and animal experimentation, began in 1905 when he spent a year at the Department of Medicine at the University of Munich. This was followed by a placement at the Institute for Infectious Diseases in Bern in 1906 where he studied under Wilhelm Kolle, a former pupil and assistant to Robert Koch, and became intrigued with paratuberculosis, an intestinal parasitical infection of cattle (it was this work that resulted in Meyer being awarded his degree in veterinary medicine from Zurich in 1909). Nonetheless, it is a measure of Meyer's intellectual curiosity that shortly after completing his undergraduate degree he sought out Dr. George Nuttall, Quick Professor of Biology at Cambridge. According to Meyer, Nuttall, an expert on the biology, structure and classification of flies, fleas, lice and ticks as vectors of disease and the author of an influential paper on the role of fleas in the transmission of plague, "foresaw many of the relationships between animal and man bridged by an insect vector", and at their meeting in Cambridge in 1906 "planted ideas in my mind that were decisive as a basis for understanding many tropical diseases" (Meyer, 1957a, p. 342). It is perhaps an indication of Meyer's desire to be remembered as an ecological thinker that he would claim that it was also Nuttall who had impressed upon him the importance of taking into account the influence on disease of topography, climate and environmental factors (Meyer, 1957a). In his interview with Daniel, Meyer also cited Ernst Haeckel, the German zoologist and Darwinist credited with coining the term ecology in 1866, and whose ideas Meyer had first 
encountered at his Realgymansium in Basel. However, though Meyer told Daniel that Haeckel had primed him to think about variations in plant and animal life, it was not until much later that he would fully appreciate his teachings, particularly his notion that, as Meyer put it, "everything in the environment has its multiple influences on all elements besides man himself" (Meyer 1976, pp. 25-26).

In his study of the later career of Robert Koch, Gradmann has shown how the German 'father of microbes' came to revise his earlier germ theory account of disease causation following his travels in East Africa in the late 1890s and his encounters with the more complex parasitical infections endemic to the tropics. According to Gradmann, this shift was largely prompted by Koch's close studies of vector-borne diseases, such as trypanosomiasis and East Coast Fever, a dangerous tick-borne infection of cattle-infections that prompted him to reassess his earlier ideas about pathogenesis and to take a closer interest in epidemiology and the role of host factors (Gradmann, 2009). In particular, Gradmann argues that Koch's African travels caused him to return to his earlier concept of the "carrier state" and the notion of latent or subclinical infections in order to make sense of the chronicity of epidemics and the appearance (or re-appearance) of disease in animal populations (Gradmann, 2010). As we have seen, by the mid-1930s Meyer had also come to regard the concept of latent infections as a way of bridging the conceptual deficits in bacteriology and, as with Koch, this journey appears to have begun in Africa when in 1909 Meyer took up a position as a pathologist at Arnold Theiler's (the father of the Nobel Prize winner Max Theiler) Veterinary Bacteriological Institute in Onderstepoort, South Africa.

Meyer's principle job at Theiler's institute was to conduct autopsies of cattle and other large animals, produce vaccines and conduct routine blood work. However, the posting also presented Meyer with an opportunity to study East Coast fever and clear up a confusion that had surrounded the transmission of the disease ever since Koch and Kolle had reported the discovery of 'blue bodies' or 'Koch's granules' in the blood of infected cattle in 1898. Although Koch suspected these bodies played a role in transmission he had been unable to reproduce East Coast fever by the inoculation of blood from affected cows into another animal. In an early demonstration of his experimental prowess and gift for deduction, Meyer showed that this was because the granules were merely the schizont or asexual stage of the parasite (later christened Theileria parva) and that it was only when ticks reingested the plasmodium during a blood meal that it transformed into a zygote and was 
able to transmit the disease to another animal (Meyer, 1909-1910). More significantly, Meyer showed that East Coast Fever could be communicated by transplanting material from the spleen and lymph of cows infected with the merozoite stage of the parasite directly into a Madagscar bull (Carter and Link, 1956, pp. 10-11; Meyer, 1909). Meyer cited the experiment as the first example of the artificial transmission of a parasitical disease independent of an arthropod vector (Meyer, 1911). However, just as important may have been the experiment's bearing on Meyer's later views of the relationship between infection and disease. ${ }^{6}$

In 1910 a chance meeting with the British ambassador to the United States led to the offer of an assistant professorship in the school of veterinary medicine at the University of Pennsylvania. Soon after, Meyer was invited to direct diagnostic work and research on animal diseases at the Pennsylvania Livestock Sanitary Board and was appointed consultant to the Philadelphia Certified Milk Commission (Sabin, 1980). This consultancy marked the beginning of Meyer's interest in brucellosis and food hygiene more generally. Known variously as undulant fever, contagious abortion and Bang's disease, brucellosis is the exemplar of a latent infection that, to use Meyer's terminology, occupies a broad "heterogeneous infection chain", the principal reservoirs being cows, goats, sheep and pigs (Meyer, 1939). ${ }^{7}$ This latency is still not well understood but is associated with the organism's ability to hide from the immune system (Wilkinson, 1993). Generally, brucella organisms infect humans via the ingestion of contaminated milk products or through the skin by direct contact with a

${ }^{6}$ One way of viewing the schizont stage of Theileria parva is as a type of latent infection that only becomes manifest when either a tick inoculates sporozoites into an animal for the first time or the merozoites of an already infected animal emerge from the spleen to invade the red blood cells. It was this latter stage of the parasite's life cycle that Meyer had precipitated through the act of transplanting a spleen infected with the schizont stage of the parasite into the bull.

${ }^{7}$ The infection chain was Meyer's attempt to group infectious diseases according to their principal animal reservoirs and vectors in order to explicate the biological and environmental constraints that dictated the transmission of disease from one type of host to another. Homogenous chains were those where transmission usually occurred within the same or closely related animal species, whereas in heterogeneous chains transmission could involve multiple animal species and intermediary arthropods. Meyer's key observation was that in heterogeneous chains "human infections are, as a rule, accidental aberrations" that, in common with other mammalian infections, "exhibit an outstanding tendency to latency or to subclinical parasitism" and usually represent evolutionary dead ends for parasites (Meyer, 1939, pp. 97-98). 
diseased animal in an occupational setting such as an abattoir. ${ }^{8}$ Once inside the body the organism takes the form of an intracellular parasite, localizing in cells in the lymph nodes, liver, spleen and bone marrow. While many brucella parasites are killed by macrophages, some survive inside cells where they are shielded from attack by the immune system (Levinson, 2008, pp. 172-173).

Meyer's first sight of the organism had come in 1908 when he isolated the Brucella meltinesis strain from a patient in South Africa. However, it was only when he arrived in Philadelphia and was invited to become a consultant to the Philadelphia Certified Milk Commission that he began to take a serious interest in the disease. At the time, American milk producers were coming under pressure to reduce the bacteria count in raw milk because of concerns it could be fueling epidemics of summer diarrhea in children. The principle target of the drive for "certified" milk was bovine tuberculosis. However, almost as soon as he began screening dairies in the Philadelphia area, Meyer noted a high incidence of abortions in dairy herds. Concerned that the cows might be infected with brucellosis, Meyer cultured the abortus organism from their milk, then isolated an antigen that he christened Abortin for use in diagnostic skin tests. Soon after, Meyer ran into Theobald Smith at a conference in Boston, where they were both presenting papers on Brucella abortus. Though Meyer was a comparative unknown in American scientific circles and 25 years Smith's junior, Smith treated him as a scientific equal, revealing that he had also isolated the abortus organism from cow's milk and suggested to Meyer that just as the melitensis organism found in goat's milk was associated with Malta Fever, so abortus organisms in cow's milk might be the source of undulant fever in humans. Perhaps more significantly, given Meyer's subsequent interest in latent infections, Smith "unrolled this really fascinating story" about how he had been able to screen for the presence of abortus in dairy herds by inoculating guinea pigs with milk from latently infected cows (Carter and Link, 1956, pp. 121-122). The guinea pigs did not develop symptoms of disease. However, at autopsy their spleens contained lesions that were always diagnostic of infection (Meyer, 1976, p. 71). ${ }^{9}$

\footnotetext{
8 There are three principal strains, B.abortus, B.melitensis and B.suis, associated respectively with cows, goats, sheep and pigs.

${ }^{9}$ Smith had first noted the lesions in guinea pigs in 1892 when he had inoculated them with cream from cattle, but as he was then looking for a way of detecting bovine tuberculosis he had not realised the significance. It was only when he was approached by the dairy industry to devise a method for screening for B. abortus and he again inoculated guinea pigs with cow's milk that he observed the same lesions and realised their significance.
} 
These two methods - the skin test with the killed Abortin antigen and the inoculation of guinea pigs with raw milk-would become Meyer's principal tools for making brucellosis in its latent form visible to American clinicians and public health officials.

Despite Meyer's claim in 1961 that he had begun formulating his biological approach to disease independently of Smith in the late 1920s, Smith was another key intellectual influence. Indeed, accepting the Walter Reed Medal in 1956, Meyer went out of his way to acknowledge his debt to Smith, saying he had first come across his work in South Africa when his investigations of East Coast Fever had made it imperative to study Smith's papers on Texas Cattle Fever, a similar tickborne disease of cattle then widely prevalent in the southern US. ${ }^{10}$ Meyer explained that Smith had not been content merely to describe the cattle-stage of the infection but had gone on to conduct a series of laborious investigations with the tick expert F. L. Kilbourne in which they showed that the parasite persisted in tick eggs deposited in the soil from where the ticks later emerged to infect a new host. The bulletin from the U.S. Department of Agriculture in 1893 describing Smith and Kilbourne's study became Meyer's "daily companion", one in which he "felt the power of one of Nature's high priests", and following their meeting at Harvard in 1910 Meyer claimed he became one of Smith's "small group of confidantes". The result was that whenever he visited the east coast, Meyer would stop at Harvard and later at Smith's home in Princeton to compare notes on the latest developments in pathology and immunology. It was also at these informal meetings that, "many years" before Smith's famous 1934 Vanuxem Lectures on 'Parasitism and Disease', Meyer claimed he had become familiar with Smith's ideas on host-parasite relationships and the role of immunising infections in regulating equilibrium states (Meyer 1957a, pp. 343-344). All of which begs the question why Meyer was so reluctant to credit Smith's influence in his interview with Daniel 5 years later? This reluctance also extends to Meyer's citations in papers where he set out his evolving biological ideas. Although Meyer's interest in latent infections and host-parasite interactions can be seen as a product of his manipulation of pathogens in small laboratory animals - practices that drew inspiration from Smith's experimental methods and his insights into immunizing processes - he does not cite Parasitism and Disease or any of Smith's prior publications on host-parasite interactions in his paper on latent infec-

${ }^{10}$ Smith's 1883 proof that Texas Cattle Fever was due to a parasite, Babesia bigeminia, was the first demonstration that bloodsucking arthropods transmitted any protozoal disease (Zinsser, 1987). 
tions (Smith, 1903, 1904, 1921, 1934; Meyer 1936a). Nor does Meyer cite Smith's insights into the biological determinants of disease in subsequent papers discussing the genesis of epidemics and host-parasite interactions (Meyer, 1937, 1939). The reason for Meyer's reticence is unclear but may be linked to his privileging of latency over virulence and his conviction that, as he put it in 1939, "infectiousness and pathogenicity are fundamentally different properties" (Meyer, 1939, p. 92). Another less charitable explanation is that, as with other biologically and ecologically-minded medical researchers in the interwar period, Meyer wanted to be remembered as the key progenitor of biological and ecological ideas within medical microbiology. In this respect, my reading of Meyer mirrors Anderson's reading of Burnet and Dubos who, he argues, also tended to present themselves "as singular, the sole author of the idea, and rarely cited others, even those linked... by education or friendship" (Anderson, 2004, p. 41). ${ }^{11}$

An assessment of Meyer's scientific career would be incomplete without a brief mention of his fraught relationship with Simon Flexner, the influential director of the Rockefeller Institute in New York. In 1913, when Flexner heard that the University of California medical school was in receipt of a $\$ 1$ million bequest from the widow of George Williams Hooper to establish a foundation for medical research and that Meyer was considering an associate professorship in bacteriology and protozoology at UC Berkeley, he tried to dissuade the young Swiss researcher, warning him that he risked "disappear[ing] in the Pacific Ocean, because the intelligentsia of the United States lives within the circumference of a hundred miles from New York" (Meyer, 1976, p. 74). Five years later, Flexner tried to entice Meyer back to the east coast by offering him a position working alongside Smith at the Rockefellerendowed department of animal and plant pathology at Princeton. However, by now Meyer had added the post of associate professor of tropical medicine at the Hooper Foundation to his portfolio and though he could see advantages in being reunited with Smith he was reluctant to relinquish his intellectual freedom, even though staying out west meant "being more or less of a lone wolf in a lonely environment" (Carter and Link, 1956, pp. 450-451). By 1924 Meyer had succeeded George Whipple as director of the Hooper and was forging a reputation as a promising young medical researcher with an innovative approach to teaching. However, according to Meyer, his pedagogical style did not

11 Indeed, Anderson points out that Burnet claimed to have only read Smith's Parasitism and Disease after he had completed the manuscript of Biological Aspects of Infectious Disease. 
meet with Flexner's approval and when in 1951 Berkeley began shortlisting directors for its new School of Public Health he learnt that Flexner had used his influence to veto his appointment. As Meyer complained to Carter a few years later: "I was obviously too confoundedly unorthodox... They [i.e. Flexner and the Rockefeller] were always pulling some darn wires because they thought I was getting too important." (p. 452). Flexner may also have been annoyed that despite an agreement with the University of California medical school that the Hooper should confine itself to the study of tropical medicine, under Meyer it had strayed too far into infectious disease research - a domain he considered the Rockefeller's property (Meyer, 1976, p. 79).

\section{Equine Encephalitis}

In his memoir of Meyer, Sabin suggests that it was Meyer's demonstration in 1930 that equine encephalitis was due to a "filterable virus" that established his scientific reputation and first brought him to the attention of the wider American public (Sabin, 1980, p. 295). Certainly, Meyer never tired of telling the story of how he had isolated the virus from a horse that he had decapitated in cloak-and-dagger circumstances in the dead of night and, repeated by De Kruif, it rapidly became the stuff of bacteriological legend, cementing Meyer's reputation as a nationally renowned microbe hunter (De Kruif, 1950). By the late 1950s, however, Meyer would claim that the Hooper Foundation's investigations of equine encephalitis in the late 1930s and early 1940s had been groundbreaking for another reason, representing an early example of what he called "a systematic ecological study" (Carter and Link 1956, p. 270). As we have seen, this was not Meyer's first reference to his new ecological principles - that had come in his De Lamar Lectures at John Hopkins'. However, in order to understand how Meyer's interest in latent infections and the multiple vectors involved in the transmission of parasites from one type of animal host to another primed him to think about disease in broader bio-ecological terms it is necessary to take a brief detour via his studies of equine encephalitis. Unlike his study of brucellosis, which was conducted largely in the laboratory, these investigations forced Meyer into the field in an effort to divine the biological and environmental factors governing the chronicity of epizootics. In the process, Meyer could not help but notice the transformations being wrought on California's Central Valley by agriculturalists and relate changes in vegetation, humidity and popu- 
lation densities to the prevalence of disease-carrying pests on farms, orchards and ranches. In this respect, Meyer's turn to ecology can be seen as a product of his keen awareness of the threats that such pests posed to the livelihoods of agricultural settlers and the need to tailor public health control measures to the environmental and ecological conditions of these Western landscapes. ${ }^{12}$ In the process, Meyer came to recognize the deficits in bacteriological epidemiology, prompting him to reach out to experts at other institutions in California and beyond. Initially, Meyer's principal collaborators were C. M. Haring, a vertebrate zoologist and the chief of veterinary science at the College of Agriculture, Berkeley; and J. C. Geiger, the director of public health for the city and county of San Francisco, who had previously worked as an epidemiologist at the Hooper. However, by 1941 Meyer had also recruited William McDowall Hammon, a mosquito and public health expert who had trained under Hans Zinsser at Harvard Medical School; William C. Reeves, a young entomologist and $\mathrm{PhD}$ candidate at Berkeley who would go on to become an expert on abor viruses and dean of Berkeley's School of Public Health; and Francis C. Evans, a mammalogist who had been recommended to him by Charles Elton. Under Meyer's tutelage this group became the focal point for the exchange of knowledge about equine encephalitis across interdisciplinary boundaries and for what Meyer called "a multi-faceted, interdisciplinary ecological [study]" (Reeves and Hammon, 1962, p. iii).

Equine encephalitis is an abor virus transmitted from birds to horses by Aedes and other species of mosquitoes. In horses and other animals it frequently attacks the optical nerves and meninges, causing the brain to swell and resulting in various types of neurological impairment. Horses afflicted by the virus typically list to one side or wander aimlessly in circles, hence the disease's colloquial name "staggers". Meyer's first encounter with the disease had come in 1914 when he was at the Pennsylvania Livestock Board and was asked to isolate the virus from the brain of a horse that died during the great Kansas-Nebraska epizootic. Unfortunately, Meyer lost the virus during passage in rabbits and it was not until 1930 when a new outbreak occurred in the San Joaquin Valley that he was able to reacquaint himself with the disease. Before the Hooper group divined the bird-mosquito-horse life cycle,

12 Anderson similarly argues that the ecological turn in Antipodean scientific circles was prompted by efforts to control agricultural and pastoral pests, such as rabbits and flying foxes, that posed a threat to settlers living in the outback, as well as by Australians' keen awareness of the legacy of colonial development and the "lasting effects of agricultural change and human resettlement" on patterns of disease (Anderson, 2004, pp. 58-59). 
equine encephalomyelitis, as the disease was then known, was thought to be a form of "forage poisoning" due to botulism (Kelser, 1933; Meyer, 1933). However, the San Joaquin epizootic had broken out in June - the wrong time of year for botulism - and veterinary experts who had visited affected ranches noted that the majority of the victims were free-ranging horses, not those that had been fed on silage or stacked hay. Altogether, some 6000 horses became diseased during the 1930 Californian outbreak and there were approximately 3000 deaths, and as the disease spread east to animals at Army barracks in the Rio Grande, Nebraska and Kansas, it was not long before the Army Veterinary Corp and agricultural colleges across the western United States were also taking an interest. By the middle 1930s Meyer was corresponding with many of these colleges and had become the focal point for the exchange of knowledge with veterinary pathologists in both civilian and military practice. At the same time, Meyer maintained a correspondence with Soviet researchers, who had observed similar epizootics of 'staggers' in horses in Kazakhstan in 1930, as well as with veterinary pathologists in Peru and Argentina (Meyer, 1934a; Vishelessky et al., 1934).

Although both the Western and Eastern strains of the disease had long been associated with free-ranging horses and mosquitoes had frequently been observed breeding in marshes close to where they grazed, before Meyer no one had thought to correlate outbreaks with unusual agricultural and topographical features of the landscape. Meyer's opportunity for a closer epidemiological study came when a new epizootic occurred in Kern County in the summer of 1931. With the help of Geiger, Meyer compiled a series of spot maps, noting how most of the cases had occurred in "irrigated areas" and that as one approached the foothills cases disappeared. These maps, Meyer later informed Daniel, were the key to his "inductive epidemiology", alerting him to the possibility that equine encephalitis might be a mosquito-borne disease like malaria or yellow fever (Meyer 1976, p. 218).

It is characteristic of Meyer's approach that rather than entrust third party reports he visited the outbreaks in person. The result was that when in 1933 reports reached him from St Louis of cases of 'poliomyelitis' in children concurrent with a new horse epizootic, Meyer was primed to challenge conventional theories as to the disease's etiology. Meyer quickly realized that many of the children had been misdiagnosed and that their symptoms more closely fitted the encephalitis seen in horses. However, the key inductive leap came when he plotted the polio cases more closely and saw that they had all occurred in orphanages in mosquito-infested districts (Meyer, 1976, 
p. 219). By now other researchers were also beginning to suspect the involvement of mosquitoes, including a group at Harvard Medical School that included Bill Hammon, a colleague of the bacteriologist Hans Zinnser. In 1933 a member of this group, Major R. A. Kelser, had succeeded in transmitting the virus to horses and guinea pigs in the laboratory using Aedes mosquitoes, providing experimental proof of the principle (Kelser, 1933). However, it was not until 1941 that the Hooper team, led by Hammon and Reeves but now also including Evans, plus a physician and a vertebrate zoologist, succeeded in isolating the virus from Culex mosquitoes trapped in the wild and from chickens and ducks on which the mosquitoes had been allowed to take a blood meal (Hammon et al. 1941). Although not definitive proof of mosquitotransmission, the experiments were strong evidence and subsequent studies demonstrated that chickens were naturally infected with the virus over the winter and that it was only as summer approached and mosquito populations increased and began to feed on chickens that the virus spilled over into horses. ${ }^{13}$

However, while Meyer was happy to delegate the mosquito studies to Hammon and Reeves, he retained a close watch over the immunization studies and personally supervised the development of a vaccine at the Cutter Laboratories, which were located near the College of Agriculture in Berkeley. It was during these studies that Meyer and Haring observed how, while during initial outbreaks fatalities among horses had been high, in subsequent years the mortality rate had been far lower, such that by the third year few or no horses showed signs of disease. Coupled with evidence that a significant percentage of horses never became ill and that survivors of the original epizootic carried antibodies to the virus yet were still capable of transmitting the infection to non-immunes, Meyer hypothecated that in its natural state equine encephalitis was a latent or 'inapparent' infection that existed in biological equilibrium with its host. Disease only occurred when humans upset this natural balance by altering environmental conditions and local ecologies so as to favor a huge increase in the mosquito population alongside a ready blood reservoir of the virus. As Meyer put it in the Foreword to Reeves' and Hammon's study of the epidemiology of the outbreak in Kern County, the virus of encephalitis had probably maintained itself in

13 Reeves had joined Meyer in 1938 when he was forced to transfer to the Hooper to complete his thesis and in 1949 became one of the first graduates of the newly established school of public health at Berkeley. He would later demonstrate that chickens were useful "sentinels" for a wide-range of mosquito-borne diseases, including West Nile Fever, and would coin the term "abor virus" to describe the typical bird-mosquitobird transmission cycle (Reeves, 1993). 
a bird-mosquito cycle "since time immemorial" and most likely "would have remained inapparent had not man altered the silent desert nidus into rich agricultural areas by developing and handling the water resources, changing vegetation and humidity to favor large vector populations capable of spreading and maintaining the viruses." $\mathrm{He}$ concluded:

We see with this disease another consequence of man's intrusions into one of nature's equilibria. He, striving, for comfort and gain, created the situation for this terrible disease, to which both he and his workhorse were susceptible (Reeves and Hammon, 1962, pp. iii-v.)

\section{Psittacosis}

If Meyer's investigations of equine encephalitis forced him to reach out to experts in entomology and zoology and pay attention to the way in which changes to desert landscapes were transforming environmental and ecological conditions so as to favor the eruption of latent infections, these lessons would be become even more apparent in the case of psittacosis and plague, prompting Meyer to adopt similar interdisciplinary working methods. As Meyer put it, opening his second lecture on the "Ecology of Psittacosis and Ornithosis" at Johns Hopkins, his investigations over the previous decade had revealed "an intriguing interaction of a virus, parasitism in birds, and environmental factors", leaving him in no doubt that psittacosis, like plague, was "a self-regulatory ecological multiple factor problem" (Meyer, 1942b, p. 177). Whereas in the case of equine encephalitis, studying these interactions required Meyer to be attuned to changing conditions in the countryside, in the case of psittacosis they led back to the city and the way in which economic pressures were transforming the conditions of California's bird breeding industry.

Although by 1930 it was known that psittacosis was transmitted by parrots, before Meyer no one appreciated the extent to which the disease was also communicated by parakeets or that a large percentage of birds bred in captivity harbored the 'virus' without displaying symptoms or other apparent signs of illness. These latent infections were a particular problem in California where during the Depression many people supplemented their incomes by breeding parakeets in backyard aviaries. The urgent need for a study of psittacosis had been brought 
home to Meyer in December 1931 when three elderly women had been taken ill at a coffee club in Grass Valley, in the Sierra Nevadas, dying soon after. Doctors had attributed their deaths variously to typhoid fever, dysentery and "toxic pneumonia", but Meyer thought otherwise and employing inductive reasoning instructed the local health officer to look for a sick or dead parrot. There were no parrots involved but on visiting the woman's home the health officer found a healthy shell parakeet (Australian budgerigar) still in its cage and another one which had died and already been buried. Through exposure tests using the live parakeet, Meyer quickly established that the budgerigar was the culprit and that the bird had come from an aviary in Los Angeles and that psittacosis was endemic to breeding establishments throughout the city (Carter and Link, 1956, p. 153).

The existence of a vast bird-breeding industry in Los Angeles came as a surprise to state public health officials who had not realized the extent to which people on low incomes relied on backyard aviaries to supplement their livings. ${ }^{14}$ As with botulism-a disease that had presented a similar public health threat in the 1920s and which had led Meyer to focus on the economics and technologies of the canning industry-Meyer's immediate response was to offer a technological solution. ${ }^{15}$ At a meeting with bird breeders in Los Angeles in 1932, Meyer proposed that if they turned over 10 to 20 percent of their stock to him he would sacrifice the birds at his laboratory at the Hooper and examine them for infections. In this way, Meyer reasoned, he would be able to present those aviaries that were found to be free of disease with a clean bill of health (Meyer, 1932).

Meyer's public health concerns were informed by his realization that, like brucellosis, psittacosis was an infection with a long latency period. ${ }^{16}$

${ }^{14}$ One reason the trade was so attractive is that southern California's temperate Mediterranean climate provided the ideal year round conditions for bird breeding. Coupled with the lack of regulation or need to provide certification, this made the trade hugely profitable.

15 For Meyer's work on botulism see Sabin (1980, pp. 288-294).

${ }^{16}$ Psittacosis is a highly infectious intracellular parasite with a broad natural host range. The bacteria that transmit the disease belong to the Chlamydiaceae family and have been isolated from 460 bird species from 30 orders. The most common carriers are psittacine (parrot-type) birds, especially parakeets or budgerigars, hence the term psittacosis. However, Chlamydophila psittaci can also infect nonpsittacine birds such as pigeons and doves, giving rise to a condition known as ornithosis. Human infections are typically acquired from exposure to parakeets, although transmission has also been documented from poultry and free-ranging birds, and usually results from the inhalation of organisms aerosolized from dried faeces, which desiccate easily in cool, dry conditions. 
The difference was that, unlike brucella psittacosis was highly pathogenic. Using funds from bird breeders to finance his research, Meyer now set about trying to understand the factors governing the virulence of the parasite and the susceptibility to disease in its avian host. In particular, Meyer was anxious to establish whether Californian parakeets were an active reservoir of psittacosis and the conditions that converted latent infection with the virus into overt disease. Answering those questions would lead Meyer to make fundamental observations about the role of environmental stressors and age-incidence in birds' susceptibility to illness - observations that, in turn, would lead to new insights into the natural history of psittacosis and the relationship between host and parasite that pertained in the wild.

The principal methods available to Meyer in 1932 to test whether healthy looking birds harbored psittacosis were pathology exams, cultivation of the virus on solid media, and mouse inoculation studies. In the case of visibly sick birds, Meyer found the virus could be cultured directly from birds' organs. By contrast, in the case of well-nourished parakeets without visible lesions, often the only indication that a bird was latently infected was the presence of an enlarged spleen. In such cases, Meyer would inoculate the ground up bird spleens into mice and examine the mice's internal organs for lesions. Once he had established that parakeets in domestic breeding establishments were infected, Meyer also performed mouse passage experiments to determine the virulence of the virus (Meyer and Eddie, 1933).

By 1934 Meyer and Eddie had tested nearly 30,000 parakeets and certified 185 aviaries as psittacosis-free. In the course of their studies, they frequently found that the size of a bird's spleen provided a rough and ready guide to the extent of latent infection in a pen. In particular, Meyer found that medium-sized spleens measuring 3-5 mm were more likely to produce "a typical, acutely fatal, or latent" illness in inoculated mice than spleens measuring 7-10 $\mathrm{mm}$. Meyer also found proportionately more enlarged spleens ( $6 \mathrm{~mm}$ or greater) in young, immature birds than in older 'capped' birds, suggesting that parakeets typically contracted psittacosis as chicks in the nest and that the enlarged but noninfective spleens found in mature birds were evidence of an old sterilizing infection (Meyer and Eddie, 1933, p. 13).

Early in his investigations Meyer had noted how California's yearround sunny weather provided the perfect conditions for outdoor bird breeding. However, the key factor was the economics of the breeding trade itself. In particular, Meyer had observed that it was the stress of the close confinement of mature capped birds alongside immature birds 
in pens that propagated the spread of the virus. Addressing bird breeders in Los Angeles in 1932, Meyer took the trouble to explain this process. Every pen contained a certain percentage of "carriers", birds whose spleens showed evidence of prior infection but who did not appear unwell or visibly diseased. These healthy looking birds might carry the virus for 6 months or longer without infecting other birds in the same pen. However, if such birds were exposed to cold or sudden climatic changes, then these infections could "become activated" and the birds might "secrete the virus and infect" other birds with whom they were caged. In particular, Meyer speculated, there was a good chance they would pass the virus to young birds or "runts" (Meyer, 1932, pp. 1, $7,15)$. This was a vital clue to the natural history of psittacosis and the environmental and ecological conditions that could convert a latent infection into one of pathogenesis. The question was how this process worked - was the shedding of the virus by mature birds linked to the stress of their confinement in closed cages and, if so, what role did variations in immunity and virulence play in the susceptibility of young non-capped birds to infection and disease? These were not easy questions for Meyer to answer with the limited laboratory and intellectual tools available to him. Addressing such questions would require not only better methods for distinguishing between genetic and acquired immunity but a closer attention to the interactions between the behavior and ecology of hosts and the biology of pathogens. In short, it would require the adoption of an ecological point of view. The question is when and how did this shift in Meyer's thinking occur? Did he arrive at these ideas independently, as he would later claim, or as a result of cross-fertilization with Burnet and Elton?

To understand the background to Meyer's exchanges with Burnet it is worth setting out the chronology in some detail. By 1933 Californian breeders were under pressure to destroy infected flocks and to restock their aviaries with clean birds from overseas. As psittacosis had never been observed or reported in Australia, it was thought that native Australian parakeets would be disease-free. Meyer also assumed that such birds would possess a high susceptibility to the virus and lend themselves to comparative exposure and immunity tests (Meyer and Eddie, 1934). Accordingly, in the early summer of 1933 Meyer paid a barber on a Dollar steamship liner to bring him 200 wild budgerigars from the Australian 'bush' and on arrival in San Francisco placed the birds in quarantine. When, 4 weeks later, one of the birds died Meyer conducted an autopsy and to his "amazement" discovered it had "a very large spleen with typical lesions of psittacosis"-in other words, 
the same as had been observed in Californian parakeets (Carter and Link, 1956, pp. 166-167). Meyer immediately sacrificed 60 birds selected at random from the quarantine cages and isolated virus from the spleens, livers and nasal mucosa of eight. At first the Australian virus was found to be relatively weak but on passage it became nearly as virulent as the virus isolated from Californian birds. Moreover, when Meyer exposed some of the Australian birds to the Californian virus, the vast majority proved resistant and rapidly recovered. Perhaps the most significant finding, however, came when Meyer allowed the Australian birds to mingle freely with Californian parakeets, half of whom were already known to be latently infected: none of the Australian parakeets died and on autopsy Meyer was unable to recover virus from the birds' spleens. Although Meyer was unable to explain the nature of this immunity, he concluded that the demonstration of latent infection together with a high resistance and recovery rate in the Australian birds was strong evidence that psittacosis was endemic to Australia and that Australian parakeets were what he termed "closed carriers of a weak virus" (Meyer and Eddie, 1934).

Meyer immediately shared his findings with Charles Kellaway, the director of the Walter and Eliza Hall Institute for Medical Research in Melbourne, who happened to be in San Francisco, and on his return to Australia Kellaway informed J. H. L. Cumpston, the director of health for Canberra, prompting Cumpston to write directly to Meyer requesting further information since "we have hitherto been unaware of any suspicion of psittacosis in Australia" (Cumpston, 1934). A few weeks later, on 26 March 1934, Meyer replied, enclosing a carbon of his forthcoming paper in the Proceedings of the Society of Experimental Biology and Medicine (Meyer, 1934b). ${ }^{17}$ The exchange appears to have been the spur for Burnet to conduct a parallel study using parakeets, parrots, cockatoos, rosellas and lorikeets obtained from dealers in Adelaide and Melbourne, which had come more or less directly from the bush. Of the 274 birds examined by Burnet, 50 (18.2\%) had demonstrable psittacosis, while $33(12 \%)$ had enlarged spleens without demonstrable virus - strong evidence, Burnet suggested, that "psittacosis infection has been enzootic amongst Australian parrots for centuries" and that the spread of the infection in nature was "essentially similar to that found in infected aviaries in California" (Burnet, 1935, p.

${ }^{17}$ In the letter, Meyer informed Cumpston that "probably nobody was more surprised than myself to find psittacosis a latent virus infection in a flock of birds which appeared as healthy as any I have had the privilege of examining" and went on to tell of him of further inoculation and passage experiments. 
419). However, this still left unexplained why it was that psittacosis was sometimes quiescent and at other times resulted in pathological changes and other signs of disease. Meyer had been particularly puzzled by the finding that none of the Australian birds who had been allowed to mingle with latently infected Californian birds had succumbed to infection and that he had been unable to recover virus from their spleens. "The nature of the resistance is unknown," he wrote, "and since it is not associated with neutralizing antibodies it is difficult to determine whether it is the result of a sub-clinical infection or of maturation immunity" (Meyer and Eddie, 1934, p. 920).

While Meyer puzzled over the mechanisms responsible for regulating host immunity, however, Burnet quickly suggested an explanation. The clue came from the marked variations in virulence that the researchers had observed between the Australian and Californian strains of the virus. For Burnet these variations in virulence provided an important clue to the natural history of psittacosis and underlined the necessity of adopting what, in an address on 'inapparent virus infections' to the pathology section of the British Medical Association in Melbourne in 1935, he called "a more ecological point of view". In a paper that rehearsed many of the themes that would become familiar to medical audiences through the publication 5 years later of Biological Aspects of Infectious Disease, Burnet argued that, while it could not be ruled out that psittacosis was a "specifically Australian disease", it was more likely that it was a "universal disease of parrots, perpetuated almost wholly by way of latent infections, but always liable to show increase of virulence for its natural host and for such accidental hosts as man". All evidence pointed to the probability that psittacosis, like other pathogenic viruses, survived by serial "passage through hosts not seriously affected by such passage". That was not to say that every now and again a fatal infection could not engender a "tremendous multiplication of virus", only that in most cases such fatal infections would prove evolutionary dead ends "allowing no further transmission of the virus and hence [conferring] no survival value". In other words, the virus of psittacosis as observed in Australian and Californian parrots had achieved "the ideal compromise".

The virus is of high infectivity but of low virulence: a large proportion of parrots, perhaps all, are infected; some die, some eliminate the virus completely, but a majority harbour it in their spleens and presumably liberate infective material into their environment, most likely via the faeces. 
In this way, Burnet concluded, "the symptomless or almost symptomless infection of the natural host can be regarded as... the equilibrium condition best suited to the survival of both species (pathogenic virus and host vertebrate)" (Burnet, 1936a). ${ }^{18}$ In a subsequent letter to Meyer, Burnet hypothesized that while in the wild young birds were infected in the nest, these natural, mild infections could flare up under the stress of close confinement, resulting in the birds' losing their acquired resistance and shedding the virus (Burnet, 1936b). ${ }^{19}$ This was a crucial insight, one that squared with Meyer's observation that it was the insanitary conditions in Californian aviaries and the close confinement of mature birds alongside hatchlings that enhanced the spread of virus. "It is absolutely correct that the resistance to latent psittacosis infection is remote and the conditions which frequently prevail in aviaries and birdstores may so affect the birds that the "silent" virus is again activated," he replied to Burnet later that summer (Meyer, 1936b).

The exchange with Burnet appears to have spurred Meyer to further inquiries and he was soon quizzing shippers about conditions in pens. These showed that it was common practice to place clean unbanded Californian birds in the same pens as latently infected foreign birds, greatly facilitating the spread of virus. The result was that in the confined conditions of shipping pens the virus was readily transferred (Carter and Link, 1956, p. 163). However, while Burnet's studies of Australian birds suggested that in its natural state psittacosis was welladapted to its avian host, Meyer noted that Californian strains were far more virulent. To Meyer this difference in virulence explained the frequency of human cases observed during the 1929-1930 pandemic of parrot fever (Meyer et al., 1935). However, perhaps Meyer's most interesting finding came from his close studies of the susceptibility of mature and immature birds to infection and disease. In parakeets ex-

${ }^{18}$ Warwick Anderson concurs that it was Burnet's interest in inapparent infections that drew him into a broader consideration of disease ecology and immunity. Anderson, Natural Histories, p. 48.

19 In a paper published five months later in the Medical Journal of Australia, Burnet elaborated on this finding, observing that: "Practically all cockatoos are infected in the nest with psittacosis virus which normally produces little in the way of symptoms and no visible anatomical change beyond an enlargement of the spleen... When, on the other hand, birds are crowded into small spaces, with inadequate food and sunlight, their latent infections is lit up. The virus multiplies in many organs and is excreted in large amounts. Should such a bird come into close and repeated contact with a person over forty years of age, a severe attack of psittacosis is likely to occur." (Burnet and MacNamara, 1936, p. 88.) 
posed to massive doses of the virus, Meyer found that susceptibility to infection was fairly constant with age whereas susceptibility to disease decreased with age. In addition, in some cases he discovered both mature and immature birds were able to rid themselves of virus within 22 days, suggesting that some benefited from an innate resistance. In his 1939 Harvey lecture Meyer concluded that whether birds were naturally inoculated with psittacosis in the nest or exposed to the virus through confinement alongside mature birds in cages, immunity was "always relative" and that "on occasions the balance is disturbed in favor of the virus". [italics inserted] (Meyer, 1939, p. 116).

Interestingly, in Biological Aspects, which appeared in print the year after Meyer delivered his paper to the Harvey Society, Burnet uses very similar language in a passage discussing psittacosis (Burnet, 1940, pp. 19-24). Citing Meyer's studies, Burnet presents psittacosis as an exemplar of disease that under normal conditions poses little threat to man. This is because in its natural state psittacosis is characterized by "a well balanced, mutually successful interaction between parasite and host... [and]few parrots die or are even discommoded by the infection". Moreover, it is "very rare for infection to pass from one human being to another" (pp. 22-23). Unfortunately, Burnet continues, "man... lives in an environment constantly being changed by his own activities, and few of his diseases have attained such an equilibrium" (p. 24). Citing a recent case in Melbourne, in which cockatoos kept for several weeks in "confined and dirty quarters" in a backyard shed resulted in 14 people becoming infected with psittacosis, Burnet continues:

Something had tipped the balance in favor of the parasite. It is reasonably certain that cockatoos, left to a natural life in the wild, would never have shown any symptoms of their infection. In captivity, crowded, filthy and without exercise or sunlight, a flare-up of any latent infection was only to be expected. [italics inserted] (p. 23)

The echo of Meyer's phrase is unmistakable. At the very least it suggests that by the late 1930s both researchers were proceeding along similar lines and influencing each other's thinking and phrase-making. Indeed, giving the Dunham Lectures at Harvard Medical School in 1944, Burnet would acknowledge that Meyer and Eddie's work elucidating the conditions under which psittacosis had spread in Californian aviaries had been fundamental not only to the understanding of psittacosis "but of the general ecological problem of host-micro-organism reactions" (Burnet, 1945, p. 72). However, while in Burnet's writings such ecological perspectives are central to his account of psittacosis and are writ large, Meyer continued to 
privilege the concept of latent infections. This privileging of latency is most apparent in Meyer's De Lamar lecture on 'The Ecology of Psittacosis and Ornithosis' in which he asserts that "latent, inapparent virus infections represent the corner stone of the entire psittacosis and ornithosis problem". [italics in original] (Meyer, 1942b, p. 177). ${ }^{20}$ According to Meyer there is little point in searching an aviary for visibly sick parakeets. Rather, successful control measures rest on the application of tried and tested pathology and laboratory techniques, coupled with attention to the natural history of the parasite and the environmental conditions that can convert a latent infection into one in which parakeets become diseased and will express the virus. In contrast to his earlier writings on latency, however, in his De Lamar lecture Meyer couched his observations in explicitly ecological language. Indeed, Meyer goes out of his way to signal this shift in his thinking by highlighting the phrase he had used in his earlier Harvey lecture in italics - hence his claim that while infection in the nest usually conferred life-long resistance to the parasite, under certain conditions "the balance of the immunity may become disturbed in favor of the virus" [italics in original] (p. 190).

Intriguingly, Meyer does not cite Biological Aspects or Burnet's (1936) paper on inapparent virus infections. This is somewhat odd given that by 1941 Meyer had read and reviewed Burnet's book favorably in Science and was using Biological Aspects as a teaching aid in an advanced course in bacteriology at Berkeley (Meyer, 1941; Elberg, 1990, p. 24). ${ }^{21}$ Nevertheless, returning Burnet's earlier complement, he quotes

20 The title of Meyer's lecture was prompted by his discovery in the late 1930s that psittacosis was by no means confined to parrots and parakeets but, from time to time, also affected chickens, canaries, fulmar petrels and pigeons. Indeed, serological tests had shown that homing pigeons raised in backyard lofts and half the pigeons in New York's Central Park harboured the virus. The existence of this 'vast reservoir' of infections in extrapsittacine birds gave added urgency to control efforts and led Meyer to propose that the nomenclature be changed from psittacosis to ornithosis.

${ }^{21}$ In his review of Biological Aspects in Science Meyer went out of his way to praise Burnet's intellectual contribution to disease ecology. Thus, in a passage in which he appears to be referring as much to himself as the reader, Meyer writes that "it must be admitted that even the seasoned expert and teacher will find [Burnet's] presentation stimulating to his memory and challenging to his intellect." Elsewhere, Meyer explicitly contrasts the "anthropocentric attitude" of classically trained medical microbiologists, who conceived infection as "a struggle between man and microbe", to the new ecological perspective in which infection is viewed as a form of biological competition. But perhaps the most revealing passage comes midway through his review where Meyer admits that: "Those who by necessity were forced to interpret the dangers of infections, which emanate from the vast reservoir in the Animal Kingdom, fully acknowledge the guiding hand in the ecological concept of the epidemics produced by population regulators - the microbian or virus parasites." (Meyer, 1941). 
extensively from Burnet's scientific papers on psittacosis in Australian birds and it is difficult not to see Meyer's new appreciation of the role of ecology in regulating host-parasite relationships as a product of his exchanges with the Australian researcher. Thus, while in his paper on latent infections Meyer refers to "the equilibrium between host and invader" and talks about "balanced infections", his subsequent discussion makes it clear that he sees this balance as analogous to forms of botanical symbiosis in which host and parasite have evolved so as to live harmoniously (Meyer, 1936a, pp. 122-123). Only towards the end of his paper does he suggest that disease is not dependent on the parasite alone but is also affected by immunological factors, or as he puts it, "the host['s]... independent susceptibility for infections without pathological consequences" (p.134). By 1941, however, he sees the balance between host and parasite as something that is explicitly dependent on environmental and ecological conditions. The crucial insight is that this balance can become disturbed not as a result of the increased virulence of the parasite but when ecological conditions lead to the suppression of immunity in the host, thereby tipping the scales "in favor of the virus". Nevertheless, Meyer struggles to express his insights in modern ecological language, hence the rather clumsy formulation of ornithosis as "a self-regulatory ecological multiple factor problem" (p. 177).

This notion that epidemics are nature's way of regulating populations that have grown too large or too dense for their ecological niches is one of the central tenets of population ecology. However, while Burnet certainly popularized the idea that parasites which transmit infectious disease act as population regulators, this insight can be traced to another ecological thinker, Charles Elton (Crowcroft, 1991; Kingsland, 1995; Anderson, 2015). Moreover, the supposed regulating role played by microbial parasites is best illustrated not by psittacosis but by diseases of rodent populations, such as plague and tularemia. In particular, it was Meyer's investigations of sylvatic plague - investigations in which he actively recruited Elton's advice and expertise- that, as much as his exchanges with Burnet over psittacosis, appear to have convinced him to embrace these new ecological perspectives.

\section{Plague}

Accepting the Walter Reed Medal in 1956, Meyer would claim that before Elton outlined his "ecologic approach" in the early 1930s efforts to understand epizootics of plague had been "shrouded in mystery" and 
"occult" epidemiological theories. Once researchers began applying Elton's teachings in earnest, however, Meyer argued that much of the confusion surrounding the etiology of epizootics and their relationship to human infections had been dispelled. Indeed, it was Meyer's decision to reach out to Elton in 1938 and apply Elton's methods in cooperation with a group of "enthusiastic entomologists and mammalogists" at the Hooper Foundation that had convinced Meyer that "the foci of plague are characterized by definite ecological peculiarities in fauna, topography, climate and vegetation.. [such that] when the assembly is recognized it can now be predicted that if plague does not already exist there, it could find ideal support for its survival if it were to be introduced" (Meyer, 1957a, p. 345). Aside from his 1941 De Lamar Lectures, this is Meyer's clearest statement of his embrace of ecological perspectives. However, as with his other sporadic references to ecology it begs the question what precisely he meant by ecology and how his conception of ecology related to his ideas about latent infections, host-parasite interactions and the biology of disease?

Meyer's interest in ecology becomes more perplexing when one considers that nowhere in his writings or speeches does he mention Eugene Odum's influential model of ecosystem ecology, which led to the foundation of the Chicago School, even though by the late 1950s Odum and his graduate students were working closely with researchers in Georgia studying the transmission of malaria parasites by birds and other animals - interdisciplinary studies that mirrored the Hooper's research into the role of avian vectors in the transmission of equine encephalitis in the Yakima Valley (Odum, 1959: Mitman, 1992; Way, 2015, pp. 332-333). Nor is there any evidence that Meyer sought to foster exchanges with leading American plant ecologists or with early Californian ecological thinkers, such as Joseph Grinnell (1879-1939), the prominent biologist and zoologist who directed the Museum of Vertebrate Zoology at UC Berkeley. This is despite that fact that Grinnell was the first person to use the term "niche" to refer to an animal's ecological position in the world and was a leading member of the Society of Mammalogists, an organization whose calls in the 1930s for a more ecologically informed approach to the control of "varmints" mirrored Meyer's position on the control of plague in Californian ground squirrels (Vandermeer, 1972; Worster, 1994, pp. 274-276). ${ }^{22}$ Instead, Meyer appears to have bypassed Grinnell and other intellectual

22 Grinnell's reference to niche came in a short paper published in Ecology in 1924. Three years later Elton employed the same term to refer to an 'animal's place in its community, its relations to food and other enemies'. (Elton, 1927, p. 50). 
currents in American ecology and reached out directly to Elton in Oxford. How he first came to learn of Elton's work is unclear. One suggestion is that the introduction may have come via Robert Gladding Green, the chair of bacteriology at the University of Minnesota. ${ }^{23}$ Whichever was the case, by the summer of 1938 Meyer had become sufficiently concerned about the threat posed by endemic reservoirs of sylvatic plague in California and the limitations of traditional bacteriological methods to address the problem to write directly to Elton in Oxford. Elton responded by sending Meyer a list of recent Russian publications on plague in Siberian marmots, including works by the Soviet rodent expert, N. I Kalabukhov (Elton, 1938c). ${ }^{24}$ Soon after, Meyer wrote to Elton a second time, this time to invite him to San Francisco. As Meyer later recalled, "we knew nothing about the migration of the squirrels, we knew nothing about their distribution of fleas, we knew nothing about the type of fleas involved" (Carter and Link, 1956, p. 217). 'I said, "All right, let's go into a study of that sylvatic plague... I was a good friend of Elton's and I brought Elton out to California to see the plague situation and at that point developed an ecological approach to the whole thing" (Meyer, 1976, p. 181).

Recalling Elton's influence on this thinking about disease in the early 1960s, Meyer would single out the Oxford ecologist's writings about the relationship of animal numbers to climate and, in particular, the role that plague played in regulating the size of rodent populations (Meyer, 1960). Elton had first become interested in these regulating processes in the early 1920s when he had noted how Norwegian lemmings tended to fall victim to epizootics every three to 4 years, these epizootics coinciding with periods of maximal population and identifiable climatic cycles. By 1925 Elton's interest in the subject had led him to analyze similar fluctuations in rodent numbers in relation to plague. Drawing on Russian and Chinese studies of marmot populations in Manchuria and Mongolia dating back to the 1850 s, Elton noted how plague epizootics tended to coincide with regular climatic cycles and periods of marmot "abundance" and argued that once more data became available it ought to be possible to predict the years of rodent epizootics and relate them

${ }^{23}$ I am grateful to Susan D. Jones for alerting me to Gladding's interest in Elton's ideas of population regulation.

${ }^{24}$ By 1960, Meyer had also become familiar with the work of the Soviet zoologist and parasitologist E. N. Pavlovksy (1884-1965) who in 1939 coined the term the "nidality of human diseases" to describe the cohabitation of pathogens and human populations and their changing interactions over time (Pavlovsky, 1966). 
to climatic oscillations. More significantly, in view of Meyer's subsequent interest in the subject, Elton also warned that rodents were frequently infected with plague "in a suppressed or chronic form"-infections that were often missed by bacteriological examination - and that researchers who examined marmots in the wrong month or time of year risked overlooking their important role as "reservoirs of plague" (Elton, 1925). Elton further developed these concepts in his 1933 book, The Ecology of Animals, in which, focusing on overcrowding and the "phenomenon of over-parasitization", he outlined a theory in which epidemics acted as "automatic checks" on animal populations (Elton, 1966, pp. 54-55). The concept, which drew in large part on the work of economic biologists like Vito Volterra and A. J. Nicholson, represented a radically different way of viewing disease from germ theory models in which pathogen and host were seen as engaged in a zero-sum struggle (Kingsland, 1995, pp. 98-126). On the contrary, Elton argued that disease outbreaks were nothing more than "well-marked manifestations of the fluctuations in population" which were "almost universal among wild animals" (Elton, 1966, p. 77). By stressing that such outbreaks were governed by "biological factors" Elton hoped to focus ecologists' attention on the "optimum densities" at which host and parasite were able to maintain their numbers to the survival advantage of both (Elton, 1966, pp. 73, 55.) However, unlike Smith and Meyer, Elton did not believe that these fluctuations tended towards equilibrium. On the contrary, he criticized the "balance of nature" view that natural selection and environmental adaptations tended to result in "steady balance between numbers of different species" (p. 61).

As with his study of equine encephalitis, Meyer's plague studies initially saw him reaching out to zoologists and entomologists from nearby academic institutions. These experts included Tracy I. Storer, a zoologist at UC Davis's College of Agriculture who had previously worked as a field naturalist at the Museum of Vertebrate Zoology at Berkeley, and Dr Morris Stewart, a flea expert from the Division of Entomology and Parasitology, also based at Davis. Other important members of the group included Charles R. Eskey, the director of the US Public Health Service (USPHS) in San Francisco and an expert on the pathology of plague in rodents, and R. R. Parker, the director of the US Public Health Service's Rocky Mountain Laboratory and an expert on both plague and Rocky Mountain Spotted Fever, a tick-borne Rickettsial infection. All four lectured on an "instructional short course" on sylvatic plague that Meyer convened at UC Medical Center in San Francisco in April 1936 under the auspices of the Sylvatic Plague 
Committee of the Western Branch of the American Public Health Association (Meyer, 1936c). The three-day course was aimed at medical students and bacteriologists interested in brushing up their laboratory skills and public health workers engaged in squirrel control activities. A few years earlier, Eskey had begun sending mobile survey crews equipped with portable dissection equipment to the sites of plague outbreaks in California and adjacent states in order to examine wild rodents for visible plague lesions, comb the rodents for fleas, and bag the material for later analysis at the USPHS laboratory in San Francisco. At the same time Eskey recruited zoologists to map the breeding grounds and migration patterns of the 18 species of Citellus squirrels that were thought to be the principal sylvatic reservoirs of plague in the western US. One function of Meyer's course was to transmit these techniques to other field workers. With a view to addressing agricultural and public health concerns, on the final day of the course Meyer also arranged for E.E. Horn, a biologist with the Wild Life Research Division of the Bureau of Biological Survey at Berkeley, to give a presentation on the latest rodent control techniques. ${ }^{25}$ However, the core of the course was presentations by Storer, Stewart and Porter addressing the 'biology', 'ecology' and 'epizootiology' of plague-carrying rodents and fleas in California and adjacent states. That these presentations were informed by the latest ecological perspectives is clear from the fact that the papers included material on flea fauna, the ecology of burrows and nests, the geographical distribution of plague in relation to altitude, and the temperature and humidity patterns necessary for the survival of plague over the winter period, as well as rodent migration, hibernation and aestivation habits. In addition, Parker addressed such key ecological questions as "How is plague maintained in nature? Does it persist indefinitely in an endemic area? Are there only certain localized areas in which it persists and from which it spreads under suitable conditions? Is there any tendency towards cyclic occurrence, and if so, what are possible factors?" (Parker, 1936). In this way Meyer and his collaborators sought to broaden the usual methods and techniques employed by bacteriological epidemiology and encourage the uptake of ecological methods and perspectives. However, as with his studies of brucellosis, equine encephalitis and psittacosis, Meyer continued to privilege latent infections and the biological relationship pertaining between host and parasite in nature.

${ }^{25}$ Eskey, Horn, and Storer also served on the executive of the Sylvatic Plague Committee where, together with Meyer and Californian public health officials, they issued regular updates on the sylvatic plague situation in California and adjacent states. 
Since around 1908, it had been known that ground squirrels and other species of wild rodent could be infected with the plague bacillus and that, on occasion, such rodents suffered mass die-offs (Wherry, 1908). However, while it had been observed that hunters exposed to squirrel bites and blood sometimes contracted plague, it was not known to what extent these rodent epizootics presented a threat to human populations. Nor was it clear to what extent immunity in wild rodents enabled squirrel populations to harbor the parasite without apparent illness and maintain plague transmission during interpandemic periods. As early as 1911 George McCoy, the director of the USPHS laboratory in San Francisco, had attempted to answer this question by conducting inoculation experiments on healthy and visibly diseased squirrels from the Bay Area. These showed that apparently healthy squirrels taken from Contra Costa county were resistant to inoculation with $P$. pestis, whereas squirrels from San Mateo county, an area of the peninsula where squirrel plague was unknown, rapidly developed buboes and died. Discussing his findings, McCoy had speculated that this resistance might be an acquired immunity due to prior exposure to the bacillus or a natural resistance inherited from squirrel survivors of earlier plague epizootics (McCoy, 1911). However, short of conducting extensive field surveys, McCoy had no way of establishing which was the case and shared his frustration with Frederick G. Novy (1864-1957), the head of the University of Michigan's Hygiene Laboratory and then the leading bacteriological authority in America. Novy subsequently related their conversation to Meyer when he visited his laboratory in Anne Arbor in 1911 and, according to Meyer, it had an important influence on his subsequent biological thinking. As Meyer explained, recalling the conversation in 1957:

$\mathrm{He}$ [McCoy] couldn't infect [the squirrels] and we [i.e. Meyer and Novy] discussed this at length...Is this an acquired immunity? Or is it perhaps, a genetic immunity? Is that survival of the fittest and the genetic transfer of resistance? Which was for that time quite a step to analyze the host disposition to an infection. And I think that had something to do with my subsequent thinking... [italics inserted]. In other words, in 1911 the concept that the genetic make-up of the host might have something to do with the acceptance of the parasite. Well it was known very well in connection with nematodes and trematodes that genetic factors gave you a specific ability to accept a host or to repel the host. But when it came to bacteria no one ever talked that way. (Carter and Link, 1956, pp. 196-197). 
The spur for Meyer's own plague studies had come in 1914 when the USPHS made the premature announcement that all "discoverable" plague had been eradicated from California. Five years later, however, the USPSHS had to revise its position when there was an outbreak of pneumonic plague in Oakland, killing 13 people (Meyer, 1942a, pp. 145-147). The possibility that wild Californian rodents might be the vectors of a disease that, while exhibiting no peculiar pneumotropic qualities, might be as deadly as marmot-derived Manchurian strains concentrated the minds of state public health officials, raising the prospect that "even in the most civilized environment like Oakland you could have the Middle Ages appearing in the form of pneumonic plague outbreak" (Carter and Link, 1956, p. 202). These fears were to become a source of ongoing tension between Meyer and state public health officials, hampering Meyer's efforts to persuade them that, although squirrels could act as reservoirs for the bubonic form of the disease, the threat of pneumonic plague was remote and that the poisoning of squirrel burrows likely to be counterproductive. ${ }^{26}$

To answer the question where plague went between outbreaks, Meyer realized it would be necessary to adapt standard bacteriological techniques and take the laboratory to the field. In the early 1920s the standard procedure for detecting plague in ground squirrels was to trap the squirrels, pack the carcasses in milk cans and ship them to a laboratory for post-mortem examination. In 1924, however, an outbreak in the Mexican quarter in eastern Los Angeles in which 31 people were infected with pneumonic plague prompted county health officials to alter their approach (Meyer, 1957b). As in previous outbreaks, suspicion initially fell on rats which are usually host to the Xenopsylla cheopis species of plague flea. However, a survey of a grocery store in the Mexican quarter had revealed only one infected rat. As the premises were a long way from port and all the rats between the port and the Mexican quarter had been shown to be free of plague, Meyer recommended that county health officials investigate whether squirrels were implicated. Accordingly, the county laboratory collected fleas from a large number of rats in the circumference of Los Angeles and the San Fernando valley (Meyer, 1976, p. 178). To their surprise they found the rats harbored Diamaus Montanus and Hoplopysllus anomalus, species of flea more commonly associated with ground squirrels, implying that the

\footnotetext{
${ }^{26}$ It would later be shown that the extreme infectivity and high mortality associated with the Manchurian plague epidemics probably had less to do with climactic conditions in northern China that to the peculiar pneumotropism of marmot-derived strains of Yersinia pestis. For further discussion see Orent (2004, p. 206).
} 
rats had been in contact with ground squirrels and an exchange of ectoparasites had taken place (Carter Papers, 'Sixth Interview', p. 209). Soon after, a virulent epizootic was observed in ground squirrels at a ranch in San Luis Obispo County, in southern California, where a similar mass die-off of rodents had been observed in 1908 (Meyer, 1942a, p. 148). ${ }^{27}$ This was followed in 1928 by a national guard at Fort Ord contracting bubonic plague, resulting in a renewed clamor for action such that the state department of public health agreed to take over survey control work from the federal government and send crews equipped with mobile laboratories into the surrounding woods. As the leading bacteriological authority and expert in animal pathology in the Bay Area, Meyer became the crews' technical advisor. One of his first steps was to insist that instead of placing squirrel carcasses in milk churns and shipping them to his laboratory, where they often arrived in an advanced state of decomposition, survey crews should dissect the rodents in the field. Meyer also gave instructions for anatomically interesting organs to be placed in glass containers and shipped on ice to the Hooper where he could examine them at his leisure. In addition, he instructed survey crews to kill and collect other rodents in the periphery of the plague focus (Meyer, 1942a, pp. 148, 179). "In this way", Meyer recalled, "I got an awful lot of insight into the ecology of plague and I began to get myself very much interested in what is the ecology of this whole business" (Carter and Link, 1956, p. 214).

The succeeding 4 years saw further squirrel epizootics with sporadic human cases, confirming Meyer's suspicion that the low infection rate discoverable in squirrels using standard detection tests did not provide an accurate measure of the extent and distribution of the "smoldering" infection (Meyer, 1942a, p. 150). ${ }^{28}$ It was not until 1934, however, that Meyer hit on a technique for revealing the true incidence of plague. The impetus came when a man in Whittier near Los Angeles suddenly developed bubonic plague and died. The weekend before he had been hunting at his cabin in the San Bernardino Mountains. Meyer had previously been to the region to study relapsing fever, a tick-borne disease of rodents, and during the visit had autopsied several squirrels and chipmunks and declared them free of plague. But based on the incubation time of the Whittier case, Meyer was certain the man must have contracted plague during his visit to his cabin and that his tech-

\footnotetext{
27 These outbreaks prompted Meyer to retrospectively designate 1924 "a sylvatic plague year in California".

${ }^{28}$ It was around this time that Meyer would later claim, he began to coin the term "sylvatic plague" (Meyer, 1976, p. 180).
} 
nique of examining squirrels for lesions and inoculating their organs into guinea pigs was inadequate. Instead, he proposed returning to an old technique that had been used by Shibasaburo Kitasato during the rat plagues in Yokhoma and Tokyo in 1899: namely, combing rats for fleas, then grinding up their bodies and inoculating the material into guinea pigs. Accordingly, survey crews were sent to the San Bernardino mountains and collected 1,000 squirrels and 60 pools of combed fleas. At autopsy, none of the rodents had visible plague lesions but three of the flea pools were virulent for guinea pigs (Meyer, 1976, p. 180). This method - the inoculation of ground fleas into guinea pigs - was to prove the key to making latent plague infections visible to public health authorities. $^{29}$

Perhaps the event which did most to shake the perception that plague was a predominantly rat-borne disease were the further mass die-offs observed in Citlleus beechyi squirrels in Kern and Tulare counties in the foothills of the Sierra Nevadas in 1934. This outbreak appears to have left an indelible impression on Meyer. Recollecting the scene in 1957, Meyer described "blowflies coming out of the burrows, the hawks flying over the landscape, skulls and furs lying around and desiccated squirrels dried up black". The conflagration, was " 250 miles from the nearest area where plague had ever been seen," Meyer recalled. "In other words it had suddenly jumped across the big San Joaquin Valley" (Carter and Link, 1956, p. 216). This was followed by further mass die-offs in Modoc county, along the Californian-Oregon border, involving another species of squirrel, Citellus oregonus. The discovery that plague had spread from the Sierra Nevadas into the Great Basin section of Oregon prompted the USPHS to dispatch mobile plague survey crews across the border in what would prove a monumental survey effort - one that was to eventually encompass 11 Pacific coast and Rocky Mountain states and which would result, by 1935, in the examination of 100,000 wild rodents and the collection of over 300,000 fleas (Eskey et al., 1940, pp. 2-4). ${ }^{30}$ It also seems to have convinced Meyer it was not sufficient to

${ }^{29}$ Indeed, using Meyer's method, Eskey found that the inoculation of fleas recovered from burrows was twice as likely to demonstrate the presence of plague and produce disease in guinea pigs as the examination of tissue and the inoculation of the organs from wild rodents (Eskey et al., 1940, pp. 75-80).

${ }^{30}$ In general, Eskey found that Cittellus beechyi were colonized by two species of flea: Diamanus and Hoplopsyllus anomalus. However, while host specificity was the norm, in areas where there was close contact between squirrels and other wild rodents, or where other rodents made use of squirrel burrows, there could be an interchange of ectoparasites and squirrel fleas could become adapted to wood rats or field mice (Eskey et al., 1940, pp. 2-4). 
scour the scene of an epizootic for rodent cadavers and fleas and transport the diseased material to the Hooper. To ascertain the extent to which sylvatic plague posed a threat to human populations it would be necessary to assemble an interdisciplinary team and make a systematic study of wild rodent populations, their ectoparasites, and the ecological and environmental conditions that regulated their densities and the circulation of $P$. pestis in nature. Accordingly, in 1936 Meyer set about assembling an interdisciplinary ecological team. The key members were Tracy Storer, the zoologist from UC Davis, the flea expert Morris Stewart, and Charles M. Wheeler, a parasitologist-pathologist who would later become known for his groundbreaking work on pesticides. Meyer also recruited a mammalogist, R. Holdenried, and two zoologists from Berkeley's Museum of Vertebrate Zoology, E. R. Hall and J. M. Linsdale (Meyer, 1942a, p. 159). In addition, in 1939, on Elton's recommendation, Meyer recruited Francis C. Evans (Elton, 1939).

Meyer selected three sites for the group's ecological studies: a biological field station near Bass Lake in Madera County in the Sierra Nevada mountains; Calaveras Dam, in Alameda County; and a ranch in Kern County. The principal objective was to study the breeding and migration patterns of Citellus beechyi and their interactions with wood rats and white-footed mice, who Meyer suspected of being the principle 'peddlers' of sylvatic plague between adjacent squirrel groups. At the same time, the group would seek to ascertain which species of flea were harbored by the ground squirrels and in what numbers, and what their relationship was to fleas that lived on other rodents. In particular, Meyer was eager to establish the density of infective fleas necessary to maintain plague in a given rodent population and the conditions under which a flea specialized in one species of rodent was able to transfer the parasite to another species. (Meyer, 1942a, pp. 159, 165-166).

Meyer appears to have had three motivations for bringing Elton to California. The first was to familiarize him with the latest experimental work at the Hooper, where the Rosenberg Foundation had just pledged $\$ 24,000$ for the construction of a new plague laboratory. The second was to have Elton visit the Hooper's field station at Bass Lake in the Sierra Nevadas and offer his assessment of the Hooper team and its ecological survey methods. The third was to furnish Meyer with a report that could be used to bolster his authority with Californian state public health officials who were skeptical of his ecological approach and were bent on stringent rodent control measures. Meyer's approach to Elton was successful and on 1 October 1938 Elton caught a flight from Washington DC, where he had been visiting the US Bureau of Bio- 
logical Survey, arriving in San Francisco the next morning in time for a breakfast meeting with Meyer who, according to Elton, was "already talking business and ecology" (Elton, 1938a).

Elton spent the first day touring the Hooper and meeting key laboratory personnel. Next, Meyer arranged for Elton to visit the Museum of Vertebrate Zoology at Berkeley. Grinnell was absent but Elton was introduced to most of the senior staff, including Jean Linsdale, a mammalogist who was engaged in squirrel population studies on behalf of the museum at a rival experimental station, and it was during this visit that Elton became aware of a "strong rift" between Linsdale and Storer over "the ethics and practice of rodent destruction in California". ${ }^{31}$ Perhaps in an effort to heal this rift, Meyer had arranged for Elton to give a lantern lecture to students and faculty members followed by dinner afterwards at the Faculty Club. Elton records that the dinner was attended by both Storer, Linsdale, and various agricultural and public health officials with responsibility for rodent control, including Meyer's close ally J. Geiger, the chief public health officer for San Francisco, and afterwards they retired to an adjoining sitting room where "the company alternately fired questions at me and argued more or less fiercely among themselves, for 2 hours, about epidemiology and population ideas". (Elton, 1938a). However, the bulk of Elton's diary and subsequent report is taken up by a discussion of Meyer's Bass Lake study and was broadly supportive of his ecological approach and the application of the Hooper's research to the control of plague (Elton, 1938b). This is hardly surprising given Elton's interest in promoting the applications of animal ecology and the fact that the survey at Bass Lake entailed pathologists working side by side with ecologists, making it a model for future interdisciplinary collaborations. However, Elton also appears to have been genuinely impressed with the facilities at Bass Lake and, despite his misgivings about some of the members of Meyer's survey team, his travel diary is full of praise for "the brilliant and daring nature of Dr Meyer's work and ideas on disease" (Elton, 1938a).

Elton opened his report with an analysis of the "general sylvatic plague situation in the United States" in 1938. The key features of this situation were: the rapid uncovering of reservoirs of plague in at least ten Western states; the possibility that plague might be spreading from west to east; and the large numbers of rodent species implicated as carriers of plague or of plague-infected fleas. In addition, Elton noted

31 In his diary Elton comments: "This rift Dr Meyer is trying to bridge, for public heath reasons, especially as regards research on rodent populations, which is in danger of settling into two rival camps" (Elton, 1938a). 
the "remarkable" scarcity of human cases, resulting in a "marked lack of interest among many medical men". This was despite the "undoubted connection of some or all of these [cases] with non-rat plague rodents" and the fact that what was at present an "enormous regional problem" might soon become a "national problem" should plague spread east to more densely populated urban areas. This alone would be justification for the Hooper study, argued Elton, but, in addition, it promised to enhance the understanding of the evolution of plague by elucidating the underlying epidemiological principles driving virulence and "latency of infection" (Elton, 1938b).

While acknowledging the valuable rodent survey work being done by the Californian state public health department, Elton argued these surveys were "inextricably bound up" with agricultural rodent control and the "vested" interests inherent in such large scale operations. "There is no scientific evidence at present to record the effectiveness of control," he declared, adding that such work was being conducted "with a degree of blindness and a scarcity of scientific measuring of results that is rather astonishing." In particular, Elton worried that such control measures might be interfering with the "normal" mechanisms of population regulation and might encourage mouse-like rodents, which were not as easy to control as squirrels and which could also carry plague, to take their place (Elton, 1938b).

Meyer found further reasons to thank Elton when he came to read his comments on the Hooper's survey work. Elton had arrived at Bass Lake on 5 October accompanied by Dr Storer, who Meyer had deputed to chauffer Elton between the experimental sites. The previous day Elton had stopped at Brentwood, where state health department plague crews had treated him to a demonstration of the methods for examining rats and ground squirrels for fleas. The following morning Storer had driven Elton to the San Joaquin Experimental Range, before proceeding via Madera and Merced to Bass Lake. Located below Yosemite Falls, Bass Lake was home to a large population of plague-free $C$. beechyi ground squirrels, as well as gophers and kangaroo cats, and Elton found that trap lines had already been laid around the site in an attempt to get an accurate measure of squirrel densities. The unit was under the direction of Wheeler, a parasitologist-pathologist, and two assistants whose responsibility it was to maintain the traps and carry out the census work. "There is here a nexus of relations between cattle, quail, rodents, snakes, plants, etc., which is being studied by a well-organized group of lively-minded men, and which is developing and seeking new methods and ideas exactly parallel to those of the Bureau of Animal 
Population," Elton noted (Elton, 1938a). Although the unit had only been up and running for a few months, in his report Elton went on to praise the team's "really excellent work". His main criticisms concerned the distribution of the traps and the danger that deer mice, Peromyscus maniculatus, might interfere with them, leading to an inaccurate gauge of the true size of the local squirrel population. Although he praised Wheeler's work, he also recommended the unit be put under the direction of an ecologist, rather than a pathologist. In that way, Elton argued, the ecologist would be able to concentrate on the age distribution of squirrel mortality, leaving the pathologist free to concentrate on his own specialism - squirrel mortality due to disease. The key was to develop "fool-proof census methods", he argued. Only then would it would be possible for ecologists to get an accurate measure of squirrel densities under normal conditions and use that information to inform the more generalized plague surveys being conducted by the state public health department. Elton also recommended that each specialist be provided with an understudy so that they would have time away from the field to analyze data and reflect on the results (Elton, 1938b).

Before leaving San Francisco, Elton had agreed to provide Meyer with a "short letter stating my main conclusions, for use as ammunition" with public health officials (Elton, 1938a). To judge by his report, Elton was as good as his word. However, if Elton's report helped bolster Meyer's authority, in other respects Elton's visit proved disappointing. Meyer had hoped that a close study of the relationship between wild rodent populations, their ectoparasites and the efficiency of different species of flea in transmitting plague might eventually provide a means of gauging the degree of latent infection in a particular region and thus the likelihood of epizootics recurring. However, while by 1941 it was clear that high rodent and flea densities favored the maintenance and spread of sylvatic plague, many questions remained unanswered. Foremost amongst these was the observation that not all rodents were equally susceptible to plague and that some rodent populations displayed a high degree of immunity. Such resistance, however, could not be taken as an indication that a particular rodent group was free of plague. On the contrary, in areas where plague had been endemic for some time Meyer came to realize that the relative immunity of rodents provided an index for the presence of latent infections even before diseased rats or squirrels had been located and examined. However, whether this resistance was acquired or inherited, Meyer could not say (Meyer, 1942a, p. 161). 
If Meyer was unable to solve the puzzle of host immunity and the persistence of the virus in wild rodent reservoirs his faith in inductive reasoning and the new ecological methods was undiminished, however. While acknowledging there was still much to learn about how vectorhost relationships that maintained plague as an enzootic infection in one rodent group failed to permit the "carry over" of plague to others, Meyer argued it was not simply a question of collecting more and better data. Rather, the problem was that present epidemiological and bacteriological knowledge "is burdened by hypotheses not in harmony with newer ecological thought" (Meyer, 1942a, pp. 171-172). For Meyer, it was this failure to take on board the implications of his ecological studies of plague that was at the root of his differences with public health officials.

Although Meyer's letters and papers at the Bancroft Library show him soliciting guidance from Elton about his ecological methods and the study of squirrels and their ectoparasites in their natural habitats, throughout these exchanges Meyer's focus is always on the environmental and ecological conditions that are likely to disrupt the biological balance between host and parasite pertaining in the wild. Indeed, central to Meyer's ecological conception of plague is the idea that, as he puts in his De Lamar lecture, sylvatic plague is "a self-regulating phenomenon in which man is merely an accidental host to a broad rodent parasitism in his environment" (Meyer, 1942a, p. 143). By self-regulating Meyer appears to have meant that, as with other parasitical infections, plague provides a natural mechanism for reducing populations that have grown too dense or too large for their ecological niches. By reducing the size of wild rodent populations, epizootics of plague restore them to ecological harmony, enhancing the survival of future generations. However, as the population begins to expand again and herd immunity wanes, the balance gradually shifts in favor of the plague parasite, sparking a new epizootic. The result is a perpetual cycle of highly visible epizootics interspersed with long periods of latency or endemic infection in which plague-infected rodents appear to be healthy and free of disease.

For all his embrace of Elton's ideas on the regulation of animal numbers, however, Meyer never appears to have fully shaken off the Haeckelian conception of ecology as the simple interaction of plants and animals with the wider environment. Nor was he prepared to abandon the idea that in nature host-parasite interactions result in a trade-off between virulence and transmission, or his conviction that disease was nearly always a result of man's "intrusion" into these natural equilibria. In this respect, it could be argued that Meyer was more a 
follower of Smith than Elton and remained first and foremost a parasitologist. Nevertheless, Meyer appears to have found Elton's ideas and methods highly relevant to the study of sylvatic plague and the ecological complexity that confronted him in California. Though it is beyond the scope of this paper, later Meyer would go further, arguing that Elton's insights into overcrowding and the increase in animal numbers was relevant not only to new zoonotic infections but to what he called the phenomenon of "mass disease" and the worldwide spread of pandemic influenza that had occurred at end of the First World War (Meyer, 1960).

\section{Conclusion}

When as a young medical researcher newly arrived in the United States Meyer had first contemplated a move to California he had been urged to reconsider by no less a figure than the director of the Rockeller Institute. Meyer ignored Flexner's advice and in the years and decades that followed turned the Hooper into a sort of Rockefeller of the West. At the same time, Meyer's intellectual curiosity and his search for a public health solution to the 'new' diseases that confronted him in California saw him forge links with a wide range of institutions and universities across the United States, as well as with international medical researchers in Melbourne and Oxford. Come his retirement in 1959, these scientific exchanges had convinced Meyer that the Hooper's future lay in unifying the study of animal and human ecology, but though he would be succeeded by Dr J. Ralph Audy, a tropical medicine specialist committed to this project, Meyer's wider ecological ambitions for the Hooper were never realized and in the late 1960s the Hooper's reputation began to fade (Anon, 1965; Audy, 1965). Meyer's reputation faded with it and, despite his various honors and the best efforts of Carter and Link, a biography of Meyer was never published and following his death in 1974 his achievements were rapidly forgotten.

This is a pity for there are strong grounds to regard Meyer as a pioneer of bio-ecological perspectives within medical microbiology. This paper has argued that Meyer's interest in these bio-ecological perspectives was a product of his broad-based medical education in Switzerland and his training in comparative pathology, as well as his encounters in South Africa and California with zoonoses that posed a threat to agricultural settlers and public health more generally. Initially, these investigations focused on parasitical diseases of livestock, such as East 
Coast Fever. However, by the 1930s Meyer was increasingly occupied by 'new' zoonotic diseases, such as brucellosis, equine encephalitis, psittacosis and sylvatic plague. Although these diseases were by no means unique to California, California's warm, year-round Mediterranean climate and varied topography supporting a rich diversity of fauna, coupled with the state's rapid population growth and the incursion of agricultural settlers into formerly arid desert regions, made them particularly present in the landscapes of the west.

To make sense of the complex ecologies of these animal-borne and arthropod-borne diseases, Meyer turned to an old epidemiological concept: latent infections. Meyer's interest in the concept of latency was prompted, in the first instance, by his investigations of East Coast Fever, but by the 1920s also encompassed brucellosis, and, by the 1930s, psittacosis and diseases bridged by multiple mammalian and arthropod vectors, such as equine encephalitis and plague. It was these epidemiological investigations that, together with his experimental observations, convinced Meyer that pathogenicity was not synonymous with infection and the presence of a disease-causing agent but was an abstraction form a more complex biological reality. Whereas germ theory tended to reduce this complexity to a zero-sum struggle between pathogen and host, biological perspectives suggested that such interactions need not be antagonistic but might result in the gradual adaptation of parasites to hosts, leading to equilibrium states. In particular, Meyer believed that the concept of 'infection chains' and the metaphors of 'latency' and 'balance', could help explain the chronicity of epidemics and why it was that infectious diseases such as psittacosis and plague sometimes assumed a highly pathogenic form and at other times were invisible to public health.

Meyer's focus on latent infections and equilibrium states clearly reflected his conversations with Smith in the 1920s. However, while he praised Smith's other intellectual contributions, Meyer was curiously reluctant to credit him with the language of hosts and parasites. That, claimed Meyer, had been his own idea, 'in about 1928' (Meyer, 1976, p. 255). Nor was Meyer seemingly any more eager to acknowledge Burnet's contribution to his evolving bio-ecological outlook, despite the clear influence of their exchanges over psittacosis in 1936. This may have reflected the fact that by 1938 Meyer had invited Elton to San Francisco to advise on his ecological surveys of plague and had absorbed many of his ideas about the regulation of animal populations. On this reading, it was only later that Meyer also came to admire Burnet's synthesis of Elton's ideas in Biological Aspects of Infectious 
Disease. However, while Elton thought that epidemics acted as a check on the size of animal populations, returning them to balance with their environmental niches, he argued there was no apriori reason why interactions between parasites and hosts should result in commensal states. Rather, Elton, like Burnet, emphasized competition between hosts and parasites and ecological instability. Meyer, on the other hand, appears to have believed that a parasite's principal objective was survival, not the elimination of its prey, and that under natural conditions interactions between hosts and parasites tended toward equilibrium, hence his claim that 'ideal parasitism is peaceful coexistence' (Meyer, 1960). In this respect, he was more a follower of Smith than Elton. However, my reading of Meyer's medical career and intellectual development suggests that his attachment to notions of ecological balance was also a consequence of the way in which he privileged ideas about infectivity and latency over virulence, and his view that heterogeneous infection chain events represented evolutionary dead ends for parasites.

In his writings on psittacosis Burnet employed similar metaphors to explain the biological significance of 'inapparent infections' and changes in equilibrium states. In particular, Burnet drew on Meyer's insights into the role of overcrowding and stress in lowering birds' immunity to resistance, thereby tipping the "balance... in favor of the virus [of psittacosis]". While Meyer puzzled over the biological mechanisms responsible for this process, however, Burnet rapidly synthesized them into a broader ecological framework, one in which biological and ecological terminology supplanted the old epidemiological language of latency and infection chains. On balance, it is hard to resist the conclusion that these exchanges 'tipped' Meyer's thought in a direction it might not otherwise have gone without Burnet's influence.

My study of the evolution of Meyer's ideas about disease also suggests that far from resisting what Mendelsohn calls the "fledging ideas and methods of upstart population ecology, or the premises of parasitology" Meyer was extremely receptive to these intellectual influences. This may have been because Meyer was not constrained by a narrow biochemical research program but, as director of the Hooper, was free to pursue a more expansive research agenda than he would have been at the Rockefeller - one that was alive to the epidemiological complexity of the zoonotic diseases endemic to the western United States and the challenges these presented to medical researchers interested in public health.

Meyer's receptiveness to these non-reductionist perspectives also owed a great deal to do his training in comparative pathology and his studies of animal parasites in South Africa. Indeed, long before Meyer 
met Smith, he had sought out Nuttall and absorbed his ideas about the interplay of insect vectors in the transmission of plague and other parasitical diseases. These biological perspectives clearly contributed to Meyer's disenchantment with germ theory. However, if some of these ideas can be traced to disciplines outside of bacteriology, many of them also came from within. In particular, my study suggests that Meyer's interest in latent infections and host-parasite interactions was a product, first and foremost, of his training as a veterinary pathologist and his experimental practices - practices that built on Koch's work in the tropics and drew direct inspiration from Smith. Moreover, it was through the application of standard bacteriological procedures and laboratory techniques, as well as innovations like the flea biotest, that Meyer was able to reveal the presence of these pathogens to his medical colleagues and make them more visible to public health. It was only afterwards that Meyer, seeking a theoretical framework in which to make sense of his observations in the laboratory and in the field, began to adopt the language of hosts and parasites and exchange epidemiological metaphors for explicitly biological and ecological ones. In other words, in Meyer's case there was no "ascendance of other scientists over "bacteriologists". Nor was there a "hostile" takeover from without. Rather, his embrace of ecological perspectives appears to have been a product of his intellectual curiosity and receptiveness to ideas from a range of disciplines.

\section{Acknowledgment}

This research was funded by the Wellcome Trust (grant 103159/Z/13/ $Z$ ) as part of a wider history of the intellectual origins of modern ideas of disease ecology. Versions of the paper were presented at the Centre for the History of Science, Technology and Medicine, University of Manchester; the British Society for the History of Science (Swansea 2015); and the International Society for the History, Philosophy, and Social Studies of Biology (Montreal 2015). I also wish to thank Pierre-Olivier Méthot and Christoph Gradmann for their comments on early drafts of the paper and the comments of the two anonymous reviewers. For insights into Meyer's personality and working practices I will forever be indebted to his former PhD student, Julius Schachter, who besides taking time to field my questions and respond to my emails, allowed me access to his collection of Hooper imprints and also directed to me to other important documents at the Bancroft Library, Berkeley. Finally, I would like to 
thank Polina E. Ilieva, the Head of Archives and Special Collections at USCF Library, Parnassus, and her assistant, Margaret Hughes, for granting me access to the William Elmer Carter Papers and for locating other important materials relating to Meyer's time at the Hooper.

\section{Compliance with Ethical Standards}

Conflict of interest The authors declare that they have no conflict of interest.

\section{Open Access}

This article is distributed under the terms of the Creative Commons Attribution 4.0 International License (http://creativecommons.org/ licenses/by/4.0/), which permits unrestricted use, distribution, and reproduction in any medium, provided you give appropriate credit to the original author(s) and the source, provide a link to the Creative Commons license, and indicate if changes were made.

\section{References}

Alizon, S., Hurford, A., Mideo, N., Van Baalen, M. 2009. "Virulence Evolution and the Trade-off Hypothesis: History, Current State of Affairs and the Future." Journal of Evolutionary Biology 22(2): 245-259.

Anderson, W. 2004. "Natural Histories of Infectious Disease: Ecological Vision in Twentieth-Century Biomedical Science." Osiris 2(19): 39-61.

2015. "Postcolonial Ecologies of Parasite and Host: Making Parasitism Cosmopolitan." Journal of the History of Biology. doi:10.1007/s10739-015-9407-6.

Anonymous. 1965. "The George Williams Hooper Foundation for Medical Research, University of California Medical Center, 1960-1965." Unpublished MSS, UCSF Library, Archives and Special Collections, George Williams Hooper Administrative Records 1882-1958, AR 91-30.

Audy, R. J. 1965. "The G. W. Hooper Foundation." The Hooper Newsletter, Winter. AR 91-30. UCSF Library, Archives and Special Collections, George Williams Hooper Administrative Records 1882-1958, AR 91-30.

Burnet, F. M. 1935. "Psittacosis Amongst Wild Australian Parrots." The Journal of Hygiene 35(3): 412-420.

— 1936a. "Inapparent Virus Infections." British Medical Journal 1(3915): 99-103. - 1936b. "Letter to Meyer," 17 February. BANC 76/42cz, Box 91. 1940. Biological Aspects of Infectious Disease. Cambridge:University Press. 1945. Virus as Organism: Evolutionary and Ecological Aspects of Some Human Virus Diseases. Cambridge, MA: Harvard University Press. 
1953. Natural History of Infectious Disease. Cambridge:Cambrdge University Press.

Burnet, F. M., and J. MacNamara. J. 1936. "Human Psittacosis in Australia." Medical Journal of Australia, (18 July, 1936): 84-88 (p. 88).

Carter, W. E, and Vernon Link. 1956. "Unpublished biography of Karl F. Meyer and related papers, written and compiled by William E. Carter and Vernon B. Link, 1956-1963". UCSF Library, Archives and Special Collections. MSS 63-1.

Chapin, Charles V. 1910. The Sources and Modes of Infection. 1st ed. New York, London: Wiley/Chapman \& Hall.

Cooper, J. E. 1998. "Of Microbes and Men: A Scientific Biography of René Jules Dubos." Unpublished PhD thesis, Rutgers University.

Crowcroft, P. 1991. Elton's Ecologists: A History of the Bureau of Animal Population. Chicago:University of Chicago Press.

Cumpston, J. H. L. 1934. "Letter to K. F. Meyer," 2 February. BANC 76/42 cz, Box 91.

De Kruif, P. 1950. "Champion Among Microbe Hunters." Reader's Digest, pp. 35-40.

Dolman, C. E. 2003. Suppressing the Diseases of Animals and Man: Theobald Smith, Microbiologist. Boston: Boston Medical Library.

Dubos, R. J. 1955. "Second Thoughts on Germ Theory." Scientific American 192(5): $31-35$.

- 1958. "Infection Into Disease." Perspectives in Biology and Medicine 1(4): 425-435.

Elberg, S. S. 1990. Sanford S. Elberg: Graduate Education and Microbiology at the University of California, Berkeley, 1930-1989: Interviews. Berkeley, CA:University of California.

Elton, C. S. 1925. "Plague and the Regulation of Numbers in Wild Mammals." The Journal of Hygiene 24(2): 138-163.

1927. Animal Ecology. London: Sidgwick and Jackson.

1938a. "Typescript diary of visit to Canada and USA, 29 August-17 October 1938." Charles Sutherland Elton Papers and Correspondence (1900-91), Bodleian Science Library, NCUAS 39.1.93/C.1-C.57/C.24.

1938b. "Notes on Sylvatic Plague Research in the United States, Report by Charles Elton to Dr Karl F. Meyer, on a visit to California, 2-8 October 1938." BANC 76/42cz, Box 45.

— 1938c. "Translations of Russian Publications." BANC 76/42cz, Box 83. 1939. "Letter to Karl Meyer," 3 January. BANC 76/42cz, Box 45. 1966 [1933]. The Ecology of Animals. 3rd ed. London: Methuen.

Eskey, C. R., Hass, V. H., Good, Newell E. 1940. Plague in the Western Part of the United States. Washington, D.C.:Federal Security Agency, U.S. Public Health Service.

Evans, E. E. 2003. "Resolution of Respect, Francis C. Evans, 1941-2002." Bulletin of the Ecological Society of America 84(2): 58-59.

Ewald, P. W. 2004. "Evolution of Virulence." Infectious Disease Clinics of North America 18: 1-15.

Farley, J. 1992. "Parasites and the Germ Theory of Disease." C. E. Rosenberg, J. L. Golden (eds.), Framing Disease: Studies in Cultural History. New Brunswick, N.J:Rutgers University Press, pp. 33-49.

Gessner, U. 2014. "Karl Friedrich Meyer (1884-1974): His Ambitions, Approach and Achievements." Journal of Medical Biography. doi:10.1177/0967772013506805.

Gradmann, C. 2009. Laboratory Disease: Robert Koch's Medical Bacteriology. Baltimore, MD: Johns Hopkins University Press. 
2010. "Robert Koch and the invention of the carrier state: tropical medicine, veterinary infections and epidemiology around 1900." Studies in the History and Philosophy of Science Part C 41(3): 232-240.

Griffiths, T., and L. Robin (eds). 1997. Ecology and Empire: Environmental History of Settler Societies. Edinburgh: Keele University Press.

Hammon, W. Mc. D., Reeves, William C., Brookman, Bernard, et al. 1941. "Isolation of the Viruses of Western Equine and St. Louis Encephalitis from Culex Tarsalis Mosquitoes." Science 94(2440): 328-330.

Honigsbaum, M. 2014. "In Search of Sick Parrots: Karl Friedrich Meyer, disease detective." The Lancet 383(9932): 1880-1881.

Kahn, L. H., Kaplan, B., Steele, J. H. 2007. "Confronting Zoonoses through Closer Collaboration between Medicine and Veterinary Medicine (as "One Medicine")." Veterinaria Italiana 43(1): 5-19.

Kelser, Major R. A. 1933. "Mosquitoes as Vectors of the Virus of Equine Encephalomyelitis." Journal of American Veterinary Medicine 82: 767.

Kingsland, S. E. 1995. Modelling Nature: Episodes in the History of Population Ecology, 2nd ed. Chicago, IL: University of Chicago Press.

Lederberg, J. 2000. "Infectious History." Science 288: 287-293.

Ledingham, J. C. G. 1912. The Carrier Problem in Infectious Diseases. International Medical Monographs. London, New York: Edward Arnold/Longmans, Green.

Levinson, W. (ed.). 2008. Review of Medical Microbiology and Immunology. New York:McGraw Hill Professional.

Mendelsohn, J. A. 1996. Cultures of Bacteriology: Formation and Transformation of a Science in France and Germany, 1870-1914. Unpublished PhD Thesis, Ann Arbor: University of Michigan. 1998. "From Eradication to Equilibrium: How Epidemics became Complex after World War I." C. Lawrence, G. Weisz (eds.), Greater Than The Parts: Holism in Biomedicine, 1921-1950. Oxford: Oxford University Press, pp. 303-331.

McCoy, G. W. 1911. Studies upon Plague in Ground Squirrels (in Four Parts): II. A Plague-like Disease of Rodents. Public Health Bulletin, 43. Washington, D.C: Government Printing Office.

Méthot, P.-O. 2012. "Why Do Parasites Harm Their Host? On the Origin and Legacy of Theobald Smith's "Law of Declining Virulence" 1900-1980." History and Philosophy of the Life Sciences 34(4): 561-601.

Meyer, K. F. 1909. "Preliminary note on the transmission of East Coast fever to cattle by intraperitoneal inoculation of the spleen or portions of the spleen to a sick animal." Journal of Comparative Pathology \& Therapy 22(3): 213-217.

1909-10. "Notes on the nature of Koch's granules and their role in the pathogenesis of East Coast Fever." Union of South Africa, Department of Agriculture, Report on the Government Veterinary Bacteriologist for the year 1909-1910, Pretoria: The Government Printing and Stationery Office, pp. 56-68.

1911. "Piroplasma (The Development of Piroplasma Parvum); the Cause of East Coast Fever in South Africa." Proceedings Pathological Society Philadelphia 14(2): $52-53$.

1925. "The 'Bacterial Symbiosis' in the Concretion Deposits of Certain Operculate Land Mollusks of the Families Cyclostomatidae and Annulariidae." Journal of Infectious Diseases 36(1): 1-107.

1931. "The Animal Kingdom-A Reservoir of Disease." Proceedings of Internal Medicine Chicago 8(14-15): 234-261. 
1932. "Psittacosis Meeting." Los Angeles, California, 2 March. BANC 76/42 cz, Box 89.

- 1933. "Equine Encephalomyelitis." North American Veterinarian 14: 30-48.

- 1934a. "Equine Encephalomyletis in 1933." Animal Pathology Exchange, College

of Agriculture, University of Illinois. BANC 76/42cz, Box 62.

1934b "Letter to J.H.L. Cumpston," 2 February. BANC 76/42 cz, Box 91.

1936a. "Latent Infections." Journal of Bacteriology 31(2): 109-135.

1936b "Letter to F. M. Burnet," 21 July. BANC 76/42cz, Box 91.

1936c. "Instructional Short Course on Sylvatic Plague.” BANC 76/42cz, Box 88.

1937. "Why Epidemics." U.S. Naval. Bulletin 37(2): 333-351.

1939. "The Host-Parasite Relationship in the Heterogeneous Infection Chains."

Harvey Society New York Lectures 35: 91-134.

- 1941. "Infectious Disease." Science 94(2441): 346-358.

-1942a. "The Ecology of Plague." Medicine 21(2): 143-174.

1942b. "The Ecology of Psittacosis and Ornithosis." Medicine 21(2): 175-205.

1957a. "Acceptance of the Walter Reed Medal." The American Journal of Tropical

Medicine and Hygiene 6(2): 341-346.

- 1957b. "The Natural History of Plague and Psittacosis." Public Health Reports (1896-1970) 72(8): 705-719.

— 1960. "The WHO-A Force in Human Ecology." Unpublished draft. BANC 76/ $42 \mathrm{cz}$. Box 45.

- 1976. Medical Research and Public Health. An Interview conducted by Edna

Tartaul Daniel in 1961 and 1962 sponsored by the University of California and The

National Library of Medicine. Berkeley, CA.: The Regents of the University of California.

Meyer, K. F., and B. Eddie. 1933. "Latent Psittacosis Infections in Shell Parakeets."

Proceedings of the Society for Experimental Biology and Medicine 30: 484-488.

— 1934. "Psittacosis in Native Australian Budgerigars." Proceedings Society Experimental Biology and Medicine 31(8): 917-920.

Meyer, K. F., Eddie, B., Stevens, I.M. 1935. "Recent Studies on Psittacosis." American Journal of Public Health 25(5): 571-579.

Mitman, G. 1992. The State of Nature: Ecology, Community and American Social Thought, 1900-1950. Chicago: Chicago University Press.

Moberg, C. L. 2005. René Dubos, Friend of the Good Earth: Microbiologist, Medical Scientist, Environmentalist. Washington, D.C: ASM Press.

Nash, L. 2006. Inescapable Ecologies: A History of Environment, Disease, and Knowledge. Berkeley, CA: University of California Press.

Odum, E. P. 1959. Fundamentals of Ecology, 2nd ed. Philadelphia: Saunders.

Orent, W. 2004. Plague: The Mysterious Past and Terrifying Future of The World's Most Dangerous Disease. New York: Free Press.

Parker, R. R. 1936. "Tentative Outline for Research on the Epizootiology of Sylvatic Plague in the Rocky Mountain Region and Adjacent Areas." BANC 76/42cz, Box 83, "Plague Studies".

Pavlovsky, E. N. 1966. Natural Nidality of Transmissible Diseases: With Special reference to the Landscape Epidemiology of Zooanthroponoses. Urbana: University of Illinois Press.

Reeves, W. C. 1993. Arbovirologist and Professor, UC Berkeley School of Public Health. University History Series. Berkeley, CA: University of California. 
Reeves, W. C., and W. McD. Hammon. 1962. Epidemiology of the Arthropod-Borne Viral Encephalitides in Kern County, California, 1943-1952. University of California Publications in Public health. Vol. 4, Berkeley: University of California Press.

Sabin, A. D. 1980. Karl Friedrich Meyer, 1884-1974, A Biographical Memoir. Washington DC: National Academy of Sciences of the United States of America, National Academy Press.

Simon, C. E. 1919. Human Infection Carriers: Their Significance, Recognition and Management. Philadelphia: Lea \& Febiger.

Smith, T. 1981 [1903]. "Presidential Address to the Society of American Bacteriologists, Philadelphia, 29-30 December, 1903." ASM News 47: 231-235.

- 1904. "Some Problems in the Life History of Pathogenic Microorganisms." Science 20(520): 817-832.

— 1921. "Parasitism as a Factor in Disease." Science 54: 99-108.

1934. Parasitism and Disease. Princeton: Princeton University Press.

Tilley, H. 2004. "Ecologies of Complexity: Tropical Environments, African Trypanosomiasis, and the Science of Disease Control in British Colonial Africa, 1900 1940." Osiris 2(19): 21-38.

Vandermeer, J. H. 1972. "Niche Theory." Annual Review of Ecology and Systematics 3: $107-132$.

Vishelessky, S. N, Glecker, N. E. and Bouchnev, K. N. 1934. "The Equine Encephalomyelitis of Horse." Veterinary Research Institute, Moscow. BANC 76/ $42 \mathrm{cz}$, Box 62.

Way, A. G. 2015. “The Invisible and Indeterminable Value of Ecology: From Malaria Control to Ecological Research in the American South." Isis 106(2):310-336.

Wherry, W. B. 1908. "Plague among the Ground Squirrels of California." The Journal of Infectious Diseases 5: 485-506.

Wilkinson, L. 1993. "Brucellosis." Kenneth F. Kiple (ed.), The Cambridge World History of Human Disease. Cambridge; NY: Cambridge University Press, pp. 625-628.

Woods, A., Bresalier, M. 2014. "One Health, Many Histories." Veterinary Record 174(26): 650-654.

Worboys, M. 1988. "Manson, Ross and Colonial Medical Policy: Tropical Medicine in London and Liverpool, 1899-1914." R. M. MacLeod, JL Milton (eds.), Disease, Medicine, and Empire: Perspectives on Western Medicine and the Experience of European Expansion. London: Routledge, pp. 21-37.

Worster, D. 1994. Nature's Economy: A History of Ecological Ideas. 2nd ed. Studies in Environment and History. Cambridge; New York, NY, USA: Cambridge University Press.

Zabusky, A. N. 1986. "Ecological Odyssey: The Intellectual Development of René J. Dubos." Unpublished MA thesis, Harvard University.

Zinsser, H. 1987. "Biographical Memoir of Theobald Smith, 1859-1934." Reviews of Infectious Diseases 9(3): 636-654. 